Teoria

A 


\title{
INTER TEXTUS / INTER ARTES / INTER MEDIA ${ }^{1}$
}

\author{
Claus Clüver \\ Indiana University
}

\begin{abstract}
RESU MO
Sobre as vantagens e dificuldades de reconceber Estudos Interartes como Estudos Intermidiáticos e de construir uma base teórica para tais estudos, especialmente em relação ao conceito de "mídia" e "mídias" e aos diversos sentidos de "intermidialidade" atualmente correntes.
\end{abstract}

\section{PALAVRAS - CHAVE}

Estudos Interartes, Estudos Intermidiáticos, intertextualidade, intermidialidade, intersemioticidade

Há décadas, na condição de comparativista, tenho trabalhado com a "comparação" da Literatura com algo que, embora seja de outra ordem em relação à Literatura, possa ser submetido, juntamente com esta, a um conceito geral que costumamos chamar de "arte". Minha área de interesse foi denominada nos EUA, por muito tempo, "Artes Comparadas", termo compreensível apenas para aqueles que o associavam a "Literatura Comparada". Hoje em dia, a área em que atuo recebe, em inglês, o nome de "Interarts Studies", que corresponde a "Estudos Interartes", em português, e "Interartiella studier", em sueco. ${ }^{2}$ A língua alemã, entretanto, nada tem a oferecer que seja etimologicamente comparável; ao invés disso, há anos se fala de "Intermedialität" (Intermidialidade), em especial com referência às relações textuais que pertencem ao campo de interesse dos Estudos Interartes. Isso está, por exemplo, bem nítido no título da coletânea Literatur intermedial: Musik - Malerei - Photographie - Film [Literatura intermidiática: Música Pintura - Fotografia - Cinema], organizada por Peter Zima em 1995. O adjetivo intermedial ainda soa estranho em inglês e se associa ao termo intermedia, utilizado em círculos especializados com significado bem específico. ${ }^{3}$ Até o presente momento,

\footnotetext{
${ }^{1}$ Versão ligeiramente alterada e reduzida de um ensaio publicado em alemão, com o mesmo título. In: SCHMITZ-EMANS, Monika; LINDEMANN, Uwe (Org.). Komparatistik 2000/2001: Jahrbuch der Deutschen Gesellschaft für Allgemeine und Vergleichende Literaturwissenschaft. Heidelberg: Synchron Publishers, 2001. p. 14-50.

${ }^{2}$ A sociedade que se dedica a essa área nos países escandinavos e na Islândia, e que já existe desde 1995, chama-se Nordisk Selskap for Interart-Studier (NorSIS).

${ }^{3}$ Cf. abaixo, p. 18-19 e p. 23 et seq., a discussão e exemplificação desses conceitos. Minha própria tentativa mais recente de utilizar intermedial ("intermidiático") em diferenciação a intermedia ("intermídias") foi "corrigida" sem o meu conhecimento: meu artigo foi publicado como "Concrete Poetry and the New Performance Arts: Intersemiotic, Intermedia [ao invés de Intermedial], Intercultural".
} 
encontrei o termo inglês intermediality quase que exclusivamente em trabalhos de autores que são originários lingüística e cientificamente de países de língua alemã; uma exceção é o holandês Eric Vos, cujo trabalho discutirei mais adiante. Em artigo na mesma coletânea, ${ }^{4}$ Jürgen E. Müller resume as principais teses de seu livro Intermedialität: Formen moderner kultureller Kommunikation [Intermidialidade: formas de comunicação cultural moderna] e estabelece uma distinção clara entre os adjetivos intermedia e intermedial, em língua inglesa. ${ }^{5}$ Assim como Müller, Werner Wolf, em The Musicalization of Fiction: A Study in the Theory and History of Intermediality [1999; A Musicalização da narrativa literária: um estudo sobre a teoria e a história da intermidialidade], parece contar com a possibilidade dessa formação lexical. Já Peter Wagner, organizador de Icons - Texts Iconotexts: Essays on Ekphrasis and Intermediality [1996; Ícones - textos - iconotextos: ensaios sobre écfrase e intermidialidade], e, como Wolf, professor de Literatura Inglesa, expressa sua preferência por the study of intermediality (estudo da intermidialidade) ao invés da expressão interarts studies (estudos interartes), empregada por outros estudiosos do assunto.

Pode-se perguntar, entretanto, se existe uma correspondência entre o que se entende na Alemanha por pesquisa sobre a intermidialidade e o campo de pesquisa que, nos EUA e em outros países, por enquanto ainda leva o rótulo de Estudos Interartes. Digo "por enquanto" porque tal rótulo, como espero demonstrar, torna-se cada vez mais equivocado e questionável. Frente a isso talvez fosse melhor seguir os exemplos mencionados e introduzir uma designação derivada do termo usado em alemão. Entretanto, isto seria aconselhável apenas caso se considerasse os termos "Estudo da Intermidialidade" e "Estudos Interartes" como plenamente equivalentes, como pressupõem Wolf e Wagner; ou se, após uma discussão mais aprofundada dos dois conceitos e de seus campos correspondentes, fosse possível aproximá-los tanto na formulação de tarefas quanto no método e, sobretudo, na escolha dos objetos de pesquisa. Além disso, é necessário não só esclarecer o modo como o conceito de "intermidialidade" deve ser entendido, mas também discutir se ele não é mais problemático do que sua utilização atual deixa transparecer. As explicações a seguir, portanto, buscam ao menos esboçar algumas respostas a essas questões.

$\mathrm{Na}$ tentativa de esclarecer o que se pensa atualmente quando se fala de Estudos Interartes, podemos tomar como ponto de partida o Comparativismo que, desde a publicação, em 1968, de Einführung in die Vergleichende Literaturwissenschaft [Introdução à Literatura Comparada], de Ulrich Weisstein, propôs discutir a "iluminação mútua das artes" como um dos âmbitos de interesse da área, ${ }^{6}$ seguindo o exemplo do primeiro

In: SPONSLER e CHEN. East of West, p. 33-61. Sobre a utilização mais específica de intermedium e intermedia por Dick Higgins, que fala nesse contexto também de intermediality, ver abaixo, p. 30-31.

${ }^{4}$ MÜLLER. Intermediality: A Plea and Some Theses for a New Approach in Media Studies.

${ }^{5}$ WAGNER. Icons - Texts - Iconotexts, p. [v]. Às vezes encontramos em inglês a expressão interart studies ao invés de interarts studies; por isso, alguns autores escrevem interart(s) studies.

${ }^{6}$ WEISSTEIN. Exkurs: Wechselseitige Erhellung der Künste, p. 184-97. Título em inglês: WEISSTEIN. The Mutual Illumination of the Arts, p. 150-66. 
manual norte-americano, publicado em $1961^{7}$ - ambos produtos do Programa de Literatura Comparada da Indiana University, que tem oferecido cursos sobre Literatura e outras Artes desde $1954 .{ }^{8}$ Em seu manual publicado em 1981, Manfred Schmeling incluiu a contribuição de Franz Schmitt-von Mühlenfels, "Literatur und andere Künste" [Literatura e outras Artes], indicando este campo de pesquisa como uma das seis áreas de competência da Literatura Comparada. Se naqueles anos isto ainda parecia estranho, nas décadas seguintes muitos congressos no âmbito do Comparativismo sancionaram tópicos correspondentes a este campo. E, enquanto a Literatura permanecer como o ponto de referência dominante, há boas razões para considerar o Comparativismo como o espaço adequado para os Estudos Interartes. O predomínio atual da arte da palavra sobre as outras artes neste campo de estudo é atestada por centenas de publicações a cada ano, relacionadas apenas de maneira incompleta na "Annual Bibliography on the Relations of Literature and Other Arts" [Bibliografia anual sobre as relações entre a literatura e as outras artes], por sociedades como a International Association of Word \& Image Studies e a International Association for Word and Music Studies, bem como por numerosos simpósios e congressos. Acrescente-se a isso, pelo menos nos EUA, uma intensa atividade de ensino, incentivada pela coletânea Teaching Literature and Other $\operatorname{Arts}^{10}$ [O ensino da literatura e outras artes], editada pela MLA (Modern Language Association) em 1990. Entretanto, no congresso internacional "Interart Studies: New Perspectives" [Estudos Interartes: novas perspectivas], realizado em maio de 1995 na cidade sueca de Lund, e cujos resultados foram publicados na obra Interart Poetics: Essays on the Interrelations of the Arts and Media [Poética interartes: ensaios sobre as interrelações entre as artes e as mídias], ${ }^{11}$ foram apresentados trabalhos nos quais a palavra não desempenhava nenhum papel ou, quando muito, apenas um papel subalterno - o que parece ser uma tendência em ascensão. Assim, a expressão Literatura e outras Artes é não apenas pouco apropriada para o campo de estudos, mas também deixa de abranger todo o âmbito dos interesses e preocupações atuais dos Estudos Interartes. $\mathrm{O}$

${ }^{7}$ STALLKNECHT e FRENZ. Comparative Literature. No artigo programático de abertura, Henry H. H. Remak definiu o Comparativismo como "o estudo da literatura além dos limites de um país único, bem como o estudo das relações entre, de um lado, a literatura e, de outro, outras áreas do conhecimento e de crença, como as artes (por exemplo, pintura, escultura, arquitetura, música).” REMAK. Comparative Literature: Its Definition and Function, p.3; cf. também GAITHER. Literature and the Arts, p.153-70. ${ }^{8}$ Cf. CLÜVER. Teaching Comparative Arts.

${ }^{9}$ Publicada anualmente sob a responsabilidade da Modern Language Association (MLA), editada por C. S. Brown (1952-1972), Steven P. Scher (1973-1984) e Claus Clüver (1985-1998). A bibliografia do ano de 1974 foi publicada nos Hartford Studies in Literature 7 (1974), p.77-96; desde 1985 apareceu no Yearbook of Comparative and General Literature, dividida em "General Topics", "Music and Literature", "The Visual Arts and Literature", "Film and Literature" (1974-1984), "Dance and Literature" (desde 1985); desde 1986, com índice de autores e de conceitos; bibliografia não incluida nos vol. 39, 41, 42, e 44 do YCGL. O vol. 40 contém bibliografias de 1989 e 1990; o vol. 43 (1995) contém dados parciais de 1991-1995; o vol. 45/46 (1997/1998), de 1996-1997. Publicação suspensa. Ver também BROWN. A Bibliography on the Relations of Literature and Other Arts 1952-1967.

${ }^{10}$ BARRICELLI; GIBALDI; LAUTER. Teaching Literature and Other Arts.

${ }^{11}$ LAGERROTH, LUND e HEDLING. Interart Poetics. 
subtítulo do livro sueco aproxima-se muito mais desse sentido, além de conseguir estabelecer uma interessante junção entre as artes e as mídias - mas isso só acontece depois de o título ter dado ênfase às artes, através da denominação usual, e também à Literatura e seu papel de liderança tradicional, através do uso do termo "Poética".

\section{INTER TEXTUS}

Segundo apontam os manuais, a Literatura Comparada tem tradicionalmente a tarefa de se ocupar, sobretudo, de relações textuais. Isso vale também para os Estudos Interartes. $\mathrm{E}$, se for verdade que o Comparativismo não compara nem mais, nem de forma diferente, do que os Estudos Literários (embora às vezes trate de outros objetos ou tenha outros interesses), isso também acontece, mutatis mutandis, com os Estudos Interartes, apesar de que, neste campo, a comparação explícita assume um papel mais acentuado. Independente dos tipos de textos e formas de relacionamentos envolvidos e dos interesses de estudo, a inclusão direta ou indireta de mais de uma mídia com diversas possibilidades de comunicação e representação e de vários sistemas sígnicos, bem como códigos e convenções a eles associados, lança continuamente questões sobre a base comparativa e as relações analógicas nas funções e efeitos dos meios encontrados.

Como toda a história da Literatura, assim como também a história da Arte e da Música, o Comparativismo, nos seus primórdios, ocupava-se especialmente de fontes e modelos, bem como daquilo que se chamava de influência. Tratava-se do contato passível de comprovação e às vezes hipotético entre textos, ou, mais precisamente, do contato de autores, enquanto leitores, com textos, que deixava seus vestígios concretos na própria criação. Esse contato inter textūs podia se estabelecer por vias muito complexas, que não precisamos discutir aqui. O que, então, aos poucos se tornou claro, ou foi cada vez mais considerado, foi o fato de que havia entre os "pré-textos" de um texto uma série de outros textos que não podiam ser identificados isoladamente. Entretanto, o que era passível de identificação, na maioria das vezes, não pertencia apenas a uma literatura isolada e freqüentemente relacionava-se ao âmbito de outras artes e mídias. Quando o interesse científico foi transferido do autor - que Roland Barthes declarou morto, em relação a determinados textos, e que Michel Foucault reduziu a funções autorais - para o leitor, que avançou até mesmo com certo direito para o posto de realizador do texto, a intertextualidade se complicou ainda mais, pois surgiram os "pós-textos", sem falar dos "paratextos", os quais passaram freqüentemente a ter uma influência considerável sobre a construção textual por parte do leitor. Entre esses paratextos se encontraram também textos não-verbais, como, por exemplo, imagens de capa e ilustrações. Foi decisivo para uma parte das exigências que se associam hoje aos Estudos Interartes o reconhecimento recente de que a intertextualidade sempre significa também intermidialidade - pelo menos em um dos sentidos que o conceito abrange. E isso vale não apenas para textos literários ou mesmo para textos verbais. Pelo menos quando se trata de obras que, seja lá em que forma, nas Artes Plásticas, na Música, na Dança, no Cinema, representam aspectos da realidade sensorialmente apreensível, sempre existe nos processos intertextuais de produção e recepção textual um componente intermidiático - tanto 
para a Literatura quanto, freqüentemente, nas outras artes. ${ }^{12}$ Aos poucos isso passa a dizer respeito a fenômenos mais abstratos, como, por exemplo, a narratividade e a critérios de forma e estilo. O repertório que utilizamos no momento da construção ou da interpretação textual compõe-se de elementos textuais de diversas mídias, bem como, freqüentemente, também de textos multimídias, mixmídias e intermídias. As comunidades interpretativas, que determinam e autorizam quais códigos e convenções nós ativamos na interpretação textual, influenciam também o repertório textual e o horizonte de expectativa. Mas o repertório é, em última análise, parte dos contextos culturais nos quais se realizam a produção e a recepção textual.

Estou consciente de que muitos dos conceitos e fenômenos aos quais me referi trazem consigo um peso teórico considerável. Quero aqui apenas indicar que, sobretudo entre semioticistas, uma obra de arte é entendida como uma estrutura sígnica geralmente complexa -, o que faz com que tais objetos sejam denominados "textos", independente do sistema sígnico a que pertençam. ${ }^{13}$ Portanto, um balé, um soneto, um desenho, uma sonata, um filme e uma catedral, todos figuram como "textos" que se "lêem"; o mesmo se pode dizer de selos postais, uma procissão litúrgica e uma propaganda na televisão. Contra essa ampliação do conceito de "texto" na perspectiva semiótica foi levantada a objeção de que ela conduziria a uma supervalorização do modelo lingüístico, especialmente em associação ao ato de "ler" (em sentido expressamente metafórico). Por experiência própria, penso que isso é uma questão de hábito e que a palavra "texto", na aplicação intertextual, rapidamente se torna um conceito neutro. Outro argumento volta-se, em geral, contra a ênfase exagerada nos conceitos e procedimentos semióticos no âmbito dos Estudos Interartes, pois isso implica uma redução das mídias a sistemas sígnicos. Especialmente quando se trata da diferenciação entre "textos" visuais, musicais, verbais e também multimídias, suas qualidades não-semióticas são de importância considerável. Para todos aqueles que, diferindo do C. S. Peirce da última fase, não entendem, de maneira radical, tudo como signo, esse é um argumento notável e importante, sobretudo quando o estudo de relações intermidiáticas objetiva a comprovação de diferenças. Contudo, na maioria dos estudos que, seja lá de que forma, recorre à Semiótica, esta se revela antes como uma disciplina auxiliar que nos possibilita, em muitas operações no campo dos Estudos Interartes, trabalhar com conceitos e designações transmidiáticos. Às vezes, interesses semióticos aparecem no primeiro plano de tais operações; em outros casos, objetos desse campo de estudo têm se prestado à exemplificação e ao esclarecimento de problemas semióticos. O que espero demonstrar é que a Semiótica, especialmente em um dos possíveis significados de "intermidialidade", pode ser um instrumento útil e até mesmo necessário. Assim, no título dessa seção de meu trabalho, eu poderia ter colocado, ao lado de inter textūs, também inter signa.

Além da extensão semiótica do conceito de "texto", eu apenas aludi de modo bem geral a seu desenvolvimento e sua transformação desde a década de 60 , que nos

\footnotetext{
${ }^{12}$ Em relação a isso, por exemplo, cf. BRYSON. Intertextuality and Visual Poetics.

${ }^{13}$ Sobre a extensão do conceito de texto e a relação entre texto e signo, ver a apresentação resumida de SANTAELLA. Texto.
} 
trouxe conceitos como textualidade, intertexto, autotexto e intratexto. ${ }^{14}$ Em seu livro Text: The Genealogy of an Anti-Disciplinary Object [Texto: a genealogia de um objeto antidisciplinar], John Mowitt resumiu a influente contribuição francesa para a teoria do texto como um "objeto antidisciplinar", ${ }^{15}$ ao passo que minhas observações sobre o leitor como realizador do texto remeteram ao deslocamento (pelo menos parcial) do texto para a consciência do receptor. Este deslocamento, resultado do trabalho dos franceses e também dos estudos em torno da recepção, acrescentou uma nova dimensão ao conceito de "texto" e ao seu tratamento crítico. Se o ato de recepção é um ato de constituição textual e, por conseguinte, dois observadores nunca vêem exatamente a mesma imagem, então a situação se complica ainda mais em casos em que cabem ao receptor tarefas performativas ou manipulativas. Os poemas holográficos de um Eduardo Kac, por exemplo, são acessíveis apenas quando o leitor-observador se coloca em uma determinada posição diante do texto-objeto, que existe só no espaço virtual. Através de diversos movimentos e mudanças de posições, o leitor-observador poderá produzir transformações de cores, formas, elementos escritos e palavras, que aparentemente se sucedem num espaço tridimensional, em que a seqüência e a duração nunca se repetem de forma exatamente igual. Assim, o leitor nunca vai produzir o mesmo texto. Algo semelhante acontece com textos interativos nas mídias eletrônicas. Mas também aqui, como em todos os casos em todas as mídias, aquilo que se apresenta à compreensão, interpretação e reação crítica como texto é moldado simultânea e espontaneamente através das respectivas convenções de recepção vigentes, de atitudes ideológicas e de interferências intertextuais. Não obstante, irei falar a seguir, e se não houver outra indicação, do objeto da percepção como "texto".

Minhas observações sobre intertextualidade e intermidialidade devem ter indicado, entre outras coisas, que um texto isolado - seja lá em que mídia ou sistema sígnico - pode representar um rico objeto de pesquisa para os Estudos Interartes, da mesma forma que um texto literário isolado, considerando suas implicações intertextuais, já se oferece ao comparativista, freqüentemente, como objeto de pesquisa promissor. Contudo, na maioria das vezes, tais estudos se ocupam de mais de um texto e tratam de formas de relação entre textos isolados, entre um texto e classes textuais (por exemplo, gêneros), ou entre classes textuais em diversas mídias. $\mathrm{O}$ leque dos Estudos Interartes parte dos estudos de fontes, passa por questões de periodicidade, problemas de gênero e transformações temáticas, até alcançar todas as formas possíveis de imitação que ocorrem através das fronteiras entre mídias (em formas e técnicas estruturais, tendências estilísticas, e outras mais). Os Estudos Interartes abrangem, além disso, aspectos transmidiáticos como possibilidades e modalidades de representação, expressividade, narratividade, questões de tempo e espaço em representação e recepção, bem como o papel da performance e da recitação. Incluem também conceitos cunhados pela Teoria da Literatura, como os de autor e leitor implícitos, cuja existência também se pode comprovar, por exemplo, na

\footnotetext{
${ }^{14}$ O volume 2 do periódico canadense Texte: Revue de critique et de théorie littéraire (1983) é totalmente dedicado ao tema "LIntertextualité: intertexte, autotexte, intratexte".

${ }^{15}$ MOWITT. Text. Aplicando o conceito de textualidade, desenvolvido por ele a partir das teorias francesas, Mowitt apresenta na terceira parte de seu livro "análises textuais" de Cinema e Música (no Cinema).
} 
Música. Um fenômeno como o do talento múltiplo pertence aos objetos de pesquisa específicos dos Estudos Interartes. Por outro lado, estes partilham com outras atividades transdisciplinares o interesse, hoje em dia tão intenso, por toda a sorte de contextos, práticas e instituições em que se deparam diversas artes e mídias.

Como é de se esperar, há entre os objetos de pesquisa e as funções dos Estudos Interartes, que acabei de apresentar ligeiramente, muitos que se encontram nessa forma também nas respectivas disciplinas que se ocupam de cada uma dessas artes ou mídias isoladamente. É importante notar que, nos Estudos Interartes, trata-se sempre de relações transmidiáticas que co-determinam as questões que nós levantamos a respeito dos objetos de pesquisa. Estas questões definem as tarefas e métodos do campo de estudos, e enquanto os Estudos Interartes não estiverem institucionalizados numa forma que vá além da organização de congressos, as tarefas e métodos serão descritos de acordo com a origem científica daquele que faz a descrição: um historiador de arte ou um musicólogo levantará questões diferentes em relação a um determinado objeto de pesquisa intermidiática do que um teórico de cinema ou um comparativista, e procederá também metodologicamente de outro modo. Na condição de comparativista, sempre considerei meu próprio trabalho e também minha atividade docente no âmbito dos Estudos Interartes como uma extensão de meu campo científico de origem. Em termos gerais, parece-me que este campo acompanhou a maioria das mudanças de direção que a Teoria da Literatura vivenciou nas últimas décadas. Essa completa mudança de paradigmas pode também ser observada nos Estudos Interartes. Talvez em decorrência de minha própria origem científica, para mim existe um campo de interesse bem central nas questões de tradução, em especial no que se refere à "transposição intersemiótica" em todas as suas manifestações e procedimentos paralelos de adaptação e transformação. ${ }^{16}$

Os estudos sobre esses processos se ocupam, em primeiro lugar, da representação lingüística de textos não-verbais e da transposição de textos literários para outras artes e mídias (ilustração, filmagem, musicalização como poema sinfônico e não como canção, etc.), mas percebe-se que esses procedimentos também acontecem entre mídias não-verbais. Em todos os casos de transposição intersemiótica, trata-se, pois, da mudança de um sistema de signos para outro e, normalmente, também de uma mídia para outra - conforme o que se entende por mídia. Além de serem traduções de uma linguagem para outra, tais transposições possuem, na maior parte, outras funções, pois, na visão de alguns críticos, elas são freqüentemente marcadas por seu caráter subversivo. Em todo caso, no estudo de transformações e adaptações intermidiáticas, deve-se, de preferência, partir do textoalvo e indagar sobre as razões que levaram ao formato adquirido na nova mídia. Freqüentemente, questões sobre a fidelidade para com o texto-fonte e sobre a adequação da transformação não são relevantes, simplesmente porque a nova versão não substitui o original. Mas, independente da maneira como nós olhamos a relação entre o texto-

\footnotetext{
${ }^{16}$ Ver CLÜVER. Klangfarbenmelodie in Polychromatic Poems: A. von Webern and A. de Campos (sobre a transposição do início de uma composição de Webern para o ideograma concreto multicolorido de Augusto de Campos, "lygia finge"); CLÜVER. Concrete Poetry Into Music: Oliveira's Intersemiotic Transposition; CLÜVER. Da Transposição intersemiótica (sobre questões da "tradução" de imagem em palavra e de palavra em imagem); CLÜVER. Bilder werden Worte: Zu Bildgedichten auf gegenstandslose Kunst; além disso, uma série de trabalhos sobre écfrase.
} 
fonte e o texto-alvo e interpretamos a forma e as funções do novo texto, nós também nos indagamos de que maneira a intermidialidade influencia nossa recepção do texto-fonte. Existem muitos pontos de contato entre o estudo de transposições intersemióticas e as pesquisas sobre traduções interlingüísticas, tanto em relação à metodologia quanto à definição de tarefas e metas; mesmo assim, esse estudo demanda outras competências. Sobretudo, exige uma familiaridade não apenas com as convenções e tradições da mídia representada no texto-alvo, mas também com a disciplina acadêmica correspondente. Além disso, os Estudos Interartes freqüentemente tratam de questões diferentes. Entretanto, os textos em questão nem sempre são vistos como "obras de arte".

\section{INTER ARTES?}

Desde seus primórdios até a fase em que se falava de uma "iluminação mútua das artes" e também de "Artes Comparadas", este campo de estudos se ocupava de textos nos quais se reconhecia o status de "obras de arte", de acordo com as concepções de "arte" então dominantes. Mas desde que Marcel Duchamp inventou o readymade, tornou-se cada vez mais difícil diferenciar a "arte" da "não-arte". Além disso, reconheceu-se que também textos que não pertencem às artes no sentido mais restrito do termo (como, por exemplo, a música popular) podiam ser objetos de estudos promissores. E, finalmente, considerou-se que a investigação de textos decididamente não recebidos como artísticos seja por si mesmo, seja em comparação com "obras de arte" - poderia conduzir a conhecimentos importantes nesse campo. Quanto menos os Estudos Interartes se ocupam de questões da forma e da estética tradicional, tanto mais insignificantes se tornam essas diferenciações. O reconhecimento, aliás, de que as diferenciações se baseiam em construtos motivados ideologicamente, ao invés de qualidades ontologicamente essenciais, fortaleceu a postura de alguns pesquisadores no sentido de falar de "obras de arte" apenas em determinados contextos, totalmente conscientes das implicações do termo. Por conseguinte, o rótulo "Estudos Interartes" tornou-se cada vez mais impreciso e, assim, insatisfatório, tanto em relação aos textos tratados quanto às formas e gêneros textuais. Por isso surgiu, por exemplo, a escolha de "Estudos sobre a Palavra e a Imagem" (Word and Image Studies) e "Estudos sobre a Palavra e a Música" (Word and Music Studies) para os nomes das associações mencionadas anteriormente.

Assim, não apenas por razões de intraduzibilidade para línguas como o alemão (este causa dificuldades consideráveis num discurso internacional), mas antes, ainda, devido à insuficiência da designação usada até agora, parece oportuno buscar uma denominação mais adequada para o conceito geral, que abranja todo o campo de estudo. A combinação de "artes e mídias", com a qual já nos deparamos, bem como o termo "intermidialidade", já corrente no âmbito científico alemão, sugere a escolha deste ou de outro nome bem semelhante para o uso internacional. Intermidialidade diz respeito não só àquilo que nós designamos ainda amplamente como "artes" (Música, Literatura, Dança, Pintura e demais Artes Plásticas, Arquitetura, bem como formas mistas, como Ópera, Teatro e Cinema), mas também às "mídias" e seus textos, já costumeiramente assim designadas na maioria das línguas e culturas ocidentais. Portanto, ao lado das mídias impressas, como a Imprensa, figuram (aqui também) o Cinema e, além dele, a Televisão, o Rádio, o Vídeo, bem como 
as várias mídias eletrônicas e digitais surgidas mais recentemente. Quase todas essas formas de expressão e comunicação estão institucionalizadas isoladamente; as disciplinas a elas dedicadas desenvolveram seus próprios métodos considerando os materiais (e "mídias", num outro sentido da palavra) dos objetos dos quais elas se ocupam e as funções culturais e sociais; além disso, todas elas têm consciência de sua própria identidade. Enquanto os teóricos das mídias, na sua maioria, concordam que eles trabalham com formas mistas, nas quais elementos verbais, visuais, auditivos, cinéticos e performativos agem conjuntamente, as disciplinas dedicadas às artes tradicionais, freqüentemente, têm dado pouca atenção a essas formas mistas que surgem em seu âmbito e não desenvolveram quaisquer métodos adequados que lhes fizessem justiça - até que elas se tornaram um objeto de estudo importante para os Estudos Interartes. O fenômeno dessas formas mistas também é denominado, no uso corrente alemão, "intermidialidade".

Apesar de nos depararmos ainda muitas vezes com a combinação "artes e mídias", a utilização de "intermidialidade" mostra que todas essas expressões e formas de comunicação no uso científico alemão permitem que sejam consideradas e designadas, hoje em dia, como "mídias", e que eventuais conflitos com outros usos do termo "mídia" nesse âmbito sejam solucionáveis ou acidentais. Por meio de alguns exemplos, investigaremos se a situação é realmente problemática. Nossa questão prioritária é saber se os termos "mídia" e "mídias" podem ser usados nesse sentido também em português sem maiores dificuldades.

À primeira vista, isso parece proceder sem maiores implicações. Indiquei, acima, um grupo grande dos mais diversos textos que pertencem aos objetos mais interessantes dos estudos de intermidialidade e dos Estudos Interartes. São as formas mistas - textos e gêneros textuais multimídias, mixmídias e intermídias ou intersemióticos - cujo tratamento começa, normalmente, com a investigação das relações entre os diversos elementos sígnicos e midiáticos neles contidos, independente do campo de interesse maior em que são estudados. $\mathrm{Na}$ designação dessas categorias encontra-se ancorada, de maneira fixa, o uso da palavra "mídia/s" também na terminologia dos Estudos Interartes.

\section{INTER MEDIA}

Um texto multimídia compõe-se de textos separáveis e separadamente coerentes, compostos em mídias diferentes, enquanto que um texto mixmídia contém signos complexos em mídias diferentes que não alcançariam coerência ou auto-suficiência fora daquele contexto. ${ }^{17}$ Textos puramente multimídias são relativamente raros - dependendo, de certo modo, das condições nas quais se recebe o texto e se observam isoladamente suas partes textuais. A ópera, enquanto modelo textual, é multimídia; enquanto encenação e apresentação, é uma mescla de elementos multimídias e mixmídias. Um libreto de ópera pode ser publicado e recebido por si só, do mesmo modo que a partitura; aberturas são tocadas em concertos, tenores apresentam no mundo inteiro árias operáticas, fazendo também certos gestos e mímicas; podemos ouvir a gravação de uma apresentação no rádio

${ }^{17}$ Estas são traduções de minhas definições formuladas em 1993 no artigo Interarts Studies: An Introduction, tradução portuguesa 2001 (definições: p. 341). 
ou tocá-la em CD. Mesmo entreatos de balés podem ser apresentados separadamente, mas a coreografia da encenação como um todo não pode existir por si só, e isto vale também para o cenário e o figurino, que só funcionam como tais dentro da encenação, mesmo que os trajes acabem em museus de teatro e os projetos cenográficos, em galerias de arte. Assim como a ópera, os videoclipes representam uma mídia própria "integral" na terminologia sancionada pela Intermidialidade. ${ }^{18}$ Eles são textos mixmídias, compostos pela união de um texto multimídia e de uma montagem de textos visuais: produzido para ter sua trilha sonora vendida separadamente (música e palavras: texto multimídia), o videoclipe contém também um caleidoscópio de videotextos visuais, que mostram os músicos num ambiente que se altera continuamente e, além disso, momentos narrativos, fragmentos de dança, cenas em ambientes externos e internos e (em medida crescente) efeitos visuais produzidos puramente por computador. Enquanto muitas dessas imagens podem ser relacionadas ao texto apenas de modo associativo, sem o som elas perdem também esse sentido e os ritmos de sua montagem perdem facilmente seu efeito sem os ritmos da música. O fato de que o texto visual não é nem coerente nem auto-suficiente, não podendo, consequentemente, ter existência separada, faz do videoclipe como um todo um texto mixmídia.

Enquanto Jürgen E. Müller citou sem reservas minha definição de textos multimídias e mixmídias em sua contribuição ${ }^{19}$ para a obra Intermedialität: Theorie und Praxis eines interdisziplinären Forschungsgebiets [Intermidialidade: teoria e prática de uma área de estudos interdisciplinares], organizada por Jörg Helbig em 1998, ele aceitou minha definição de textos intermídias, porém com uma ressalva. Em consideração à sua objeção, alterei ligeiramente a minha definição: "o texto intersemiótico ou intermídia recorre a dois ou mais sistemas de signos e/ou mídias de uma forma tal que os aspectos visuais e/ou musicais, verbais, cinéticos e performativos dos seus signos se tornam inseparáveis e indissociáveis". Müller fez outra sugestão: "compreender a união indissociável de diversas mídias como fusão e interação de processos e procedimentos midiáticos distintos". ${ }^{20}$ Ele extraiu, com isso, o componente semiótico da definição e o substituiu por uma concepção dinâmica do conceito de "mídia", enquanto eu prefiro falar de textos intersemióticos ao invés de textos intermídias, pois nem todo sistema sígnico é também necessariamente uma mídia. ${ }^{21}$ Contudo, no âmbito deste ensaio, ocupar-me-ei do conceito de "mídia" e das dificuldades a ele associadas apenas quando for necessário para a resposta às questões já lançadas. E, para isso, trago agora alguns textos que, assim espero, possam auxiliar a reconhecer claramente essas dificuldades de ordem geralmente conceitual.

\footnotetext{
${ }^{18}$ Aage A. Hansen-Löve fala do "gemeinsame[n] Auftreten von heterogenen Kunstformen im Rahmen eines integralen Mediums (Theater, Oper, Film, Performance etc.)" ["aparecimento de formas artísticas heterogêneas emolduradas em uma mídia integral (Teatro, Ópera, Cinema, Performance etc.)"], in: HANSEN-LÖVE. Intermedialität und Intertextualität, p. 291. Jürgen E. Müller tratou do vídeo como um caso modelo de intermidialidade, in: MÜLLER. Video - or the Intermedial State of the Art.

${ }^{19}$ MÜLLER. Intermedialität als poetologisches und medientheoretisches Konzept.

20 “[...] die unauflösbare Verbindung verschiedener Medien als Fusion und Interaktion unterschiedlicher medialer Prozesse und Verfahren zu begreifen"; MÜLLER. Intermedialität als poetologisches und medientheoretisches Konzept, p.38.

${ }^{21}$ Numa conversa com o autor, Haroldo de Campos sugeriu o termo "intercódigos" invés de "intersemiótico" - uma alternativa talvez ainda mais adequada.
} 
Peephole é um livro de artista $^{22}$ de Yara Ferreira Clüver. O leitor tem nas mãos um objeto semelhante a um livro, medindo 20,5 por $25,7 \mathrm{~cm}$ e, aproximadamente, $13 \mathrm{~mm}$ de espessura, inesperadamente pesado, cujas capas duras são revestidas por um papel de cor lilás, áspero, feito à mão. É um "livro túnel", somente legível quando é colocado em posição horizontal e a capa superior é erguida com ambas mãos. No centro dessa capa há um orifício retangular medindo 4,5 por $8,5 \mathrm{~cm}$, através do qual se lêem as definições lexicais de "peep" (espiar), "peephole" (visor) e "peer" (par, semelhante), fotocopiadas em uma cartolina amarelada (Fig. 1a). Quando se ergue a capa, o orifício torna-se um visor: o texto se divide e vê-se através da cartolina, que se desdobra como um acordeão (Fig. 1b), um novo orifício retangular com as palavras "fetid" (fétido), "fetish" (fetiche) e "fetlock" (parte traseira da pata do cavalo), rodeadas pela imagem fotográfica de um nu feminino de pé e sem cabeça. Quando se ergue novamente a capa, o texto se divide de novo e o observador se depara, através de dois visores, com a definição de "voyeur", emoldurada por uma fotografia em preto e branco, exibindo um nu masculino, deitado, num ambiente natural (uma rocha). Em seguida, esse novo texto também se divide e o observador vê... seus próprios olhos, pois a base é um espelho; a imagem dos olhos, refletida, situa-se no meio de um túnel de visores com várias molduras, em cujas bordas aparecem imagens indefiníveis de outras partes do corpo, pois também as partes inferiores das folhas exibem fotos que se tornam, então, visíveis como imagens refletidas.

Evidentemente, essa tentativa ecfrástica de unir a descrição de um objeto recebido a uma representação do ato de recepção não pode substituir a própria vivência da recepção. Diferente de um texto literário convencional, que se pode absorver pela leitura, mas também, por exemplo, ao ser ouvido pelo rádio, esse livro de artista exige ser manipulado de acordo com as regras adotadas em sua construção; o sucesso da leitura depende da habilidade do leitor, que pode frustrar o efeito de surpresa da imagem refletida, por exemplo, através de olhares laterais e inapropriados. Se a participação fisicamente ativa do leitor é de tal maneira parte do processo e ele, ao final, vê apenas o que o seu manejo lhe permite ver (além, é claro, da agradável experiência tátil da superfície do livro), então pode se dizer, mais uma vez, que o texto se constitui de fato na consciência do leitor, apesar de que este, de modo diferente ao que acontece com o "holopoema", tem nas mãos um objeto concreto.

A que mídia pertence esse livro de artista e que mídias tomam parte em sua constituição? Ou seria melhor indagarmos sobre processos midiáticos? Como estes se relacionam entre si? Esse é um texto intermídia? Podemos, de pronto, dar a resposta à última questão: pode-se retirar o espelho e ele continuará a projetar imagens refletidas. As definições lexicais encontradas prontas também existem por si mesmas. Mas o processo midiático na recepção interativa, de fato, não existe por si e as fotos reproduzidas mecanicamente, em cujo centro aparece o orifício, não podem também se tornar independentes nessa forma, apesar de existirem originalmente por si. Temos aqui uma união, mas não um amálgama indissociável de diversas mídias enquanto interação e nem uma fusão "de processos e procedimentos midiáticos distintos”. Assim, nem no sentido sugerido por Müller, nem na minha definição, trata-se de um texto intermídia. O melhor é considerá-lo como um texto mixmídia. Entretanto, com isso ainda não esclarecemos, de modo algum, o que entendemos aqui por "mídia" e quais mídias estão em jogo.

\footnotetext{
${ }^{22}$ Sobre o gênero e a história de livros de artista, ver DRUCKER. The Century of Artists' Books.
} 
Fig. 1: Yara Ferreira Clüver (n. 1963), Peephole, 1995. Livro de artista, 20,5 x 25,7 x 1,3 cm.

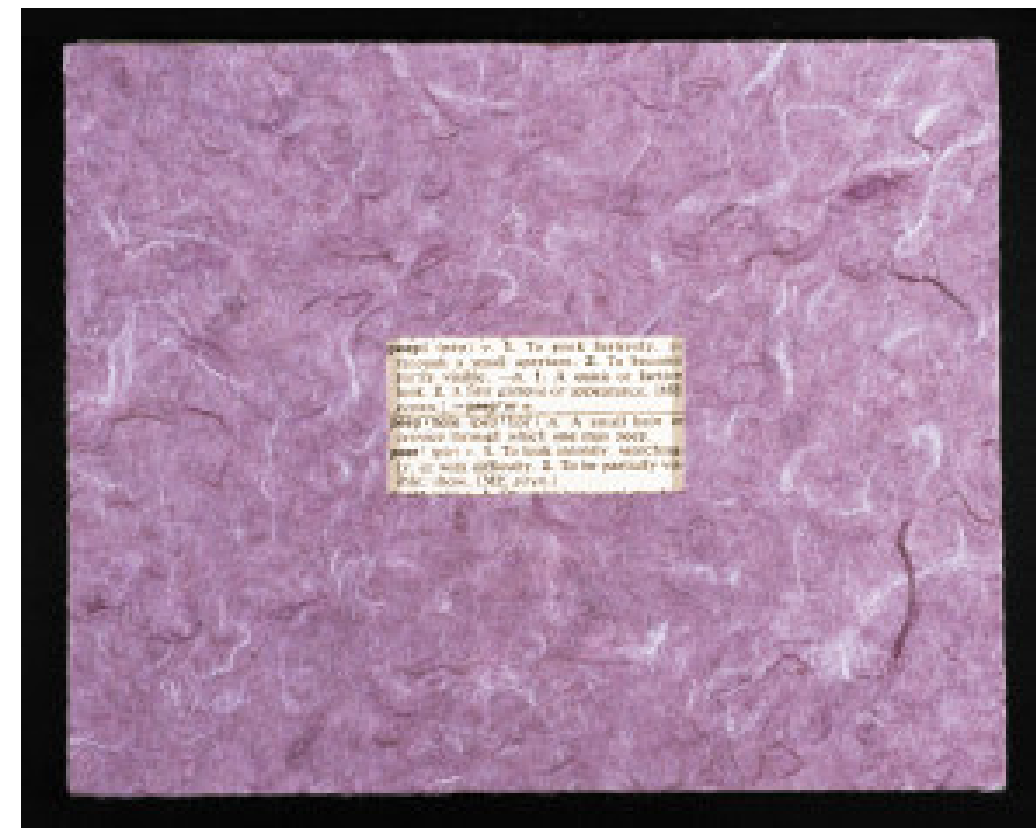

Fig. 1a: Vista de cima.

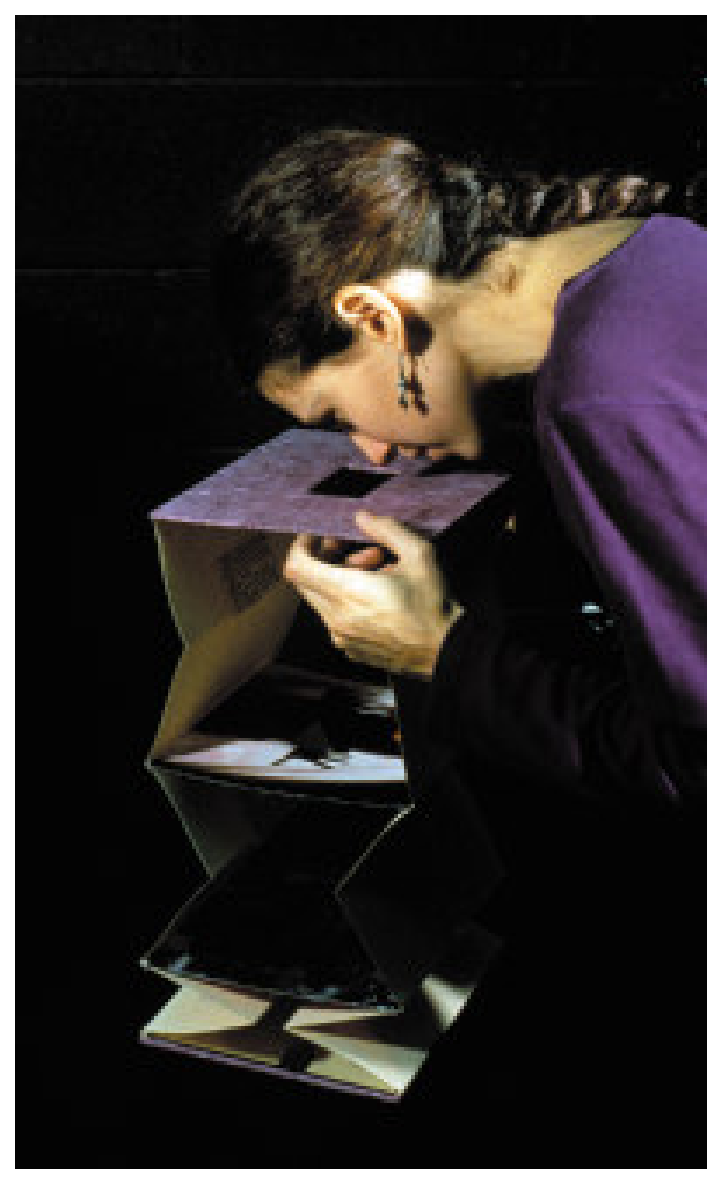

Fig. 1b: A artista lendo o livro. 
Temos diante de nós um livro que pertence a um determinado gênero (livro de artista) e que tem um formato tradicional (livro túnel), mesmo que incomum, que tem um efeito considerável no processo de leitura. O material da encadernação influencia a recepção (cor e qualidade das superfícies) e o mesmo pode-se dizer do material do suporte textual (cor e rigidez da cartolina). O livro contém textos verbais, cujo gênero é reconhecível imediatamente pela escolha e disposição dos tipos de imprensa - portanto, pela representação visual - e cuja autenticidade é garantida pelo procedimento fotomecânico de reprodução adotado: o reconhecimento espontâneo do gênero "enciclopédia" pode nos levar a ler apenas as palavras impressas em negrito, na certeza de já conhecermos as definições. Há, além do mais, textos fotográficos reproduzidos fotomecanicamente em preto e branco e em cores. E, por fim, há imagens refletidas, percebidas em permanente transformação pela manipulação do objeto como um todo, por parte do leitor.

Não é tão fácil selecionar o que é geralmente chamado de mídia entre os componentes aqui enumerados. Tipografia e fotografia são mídias, mas, como a reprodução fotomecânica, constituem também processos de produção; em minha opinião, deve-se também colocar o espelho nessa categoria. O livro, enquanto suporte textual, pertence a uma categoria semelhante, porém específica. Um livro consiste sempre de diversos materiais ou "meios físicos", e o conceito de mixed media (técnica mista ou mixmídia), tomado emprestado da História da Arte, relaciona-se nesse campo somente a esta categoria: "mármore" ou "óleo sobre tela" são a indicação "midiática" de costume. Entretanto, apesar de sempre ter havido mesclas de materiais, o termo mixed media somente se tornou realmente interessante a partir da colagem cubista. ${ }^{23} \mathrm{Na}$ música, a ele corresponde aproximadamente a inclusão de objetos não concebidos originalmente como instrumentos musicais, como a máquina de escrever ou o secador de cabelo. Mas no discurso midiático, mixed media, como vimos, refere-se a outra espécie de "mídia". No nosso caso concreto, trata-se de uma mescla de textos fotográficos e lingüísticos com imagens espelhadas num livro de artista, em que o formato visual das reproduções desempenha um papel importante. Aqui, "mídia" refere-se, portanto, a uma categoria de textos e classes textuais, às quais também pertence o livro enquanto texto e, do mesmo modo, a xerografia, pois, a rigor, os textos, do modo como os vemos sobre a cartolina, são todos textos xerográficos.

As classes textuais que aqui encontramos representadas são todas potencialmente formas de arte. Até onde se permite reconhecer, as fotografias originais possuem qualidade artística, aqui afetada pela intervenção da construção do livro e limitada em sua função

\footnotetext{
${ }^{23}$ De acordo com a enciclopédia de "Fachbegriffe zur modernen Kunst" [Conceitos especiais da arte moderna], de Karin Thomas, o verbete "Mixed Media" designa três fenômenos diversos:

1. conceito coletivo para uma ação artística interdisciplinar, executada na união midiática entre Música, Cinema, Dança, Luz, Som, Televisão;

2. característica de um objeto de arte que reúne materiais heterogêneos;

3. conceito coletivo para todas as formas de um amplo processo de colagem de materiais, por exemplo, assemblage, combine painting, environment.

THOMAS. Bis Heute, s/p. Multimedia é apresentado nessa obra como "conceito sinônimo de mixed media", "que caracteriza a junção de diversas mídias de impressão na produção artística" - portanto, como substancialmente idêntico ao primeiro significado do conceito. Nessa obra, não se encontra um verbete "Intermedia".
} 
e efeito pelos textos lingüísticos. As definições lexicais são, em si, inaceitáveis como Literatura (quer dizer, como Arte)e se tornam, justamente por isso, interessantes enquanto parte de uma obra de arte. Do mesmo modo, a aparência tipográfica desses textos verbais, evidentemente não-artística, é a única correta para esse texto artístico - o livro como um todo. $\mathrm{O}$ mesmo vale para o papel da xerografia nesse livro, que não representa o gênero recente da arte-xerox. Em suma: em ambas as línguas, inglês e português, independente de eles valerem ou não isoladamente como "arte", é possível considerar esses textos atrelados numa forma mista como textos midiáticos e, por conseguinte, ver também as artes correspondentes como mídias.

Em seu livro Intermedialität: Formen moderner kultureller Kommunikation [Intermidialidade: formas de comunicação cultural moderna], que se ocupa detalhadamente do conceito de "mídia", Jürgen Müller assume literalmente a definição formulada em 1988 por Rainer Bohn, Eggo Müller e Rainer Ruppert, segundo a qual “mídia” é aquilo "que transmite para, e entre, seres humanos um signo (ou um complexo sígnico) repleto de significado com o auxílio de transmissores apropriados, podendo até mesmo vencer distâncias temporais e/ou espaciais". ${ }^{24}$ Para as necessidades de um discurso midiático e para o esclarecimento do conceito de "intermidialidade", essa definição parece ser inteiramente plausível; entretanto, a frase "com o auxílio de transmissores apropriados", embora seja por um lado necessária e útil, por outro lado não esclarece se os próprios transmissores seriam, com isso, excluídos do campo definido. Não queremos decidir essa questão aqui. Com exceção dos meios físicos, entre os quais figuram a cartolina amarelada e o espelho (assim como a tela e as tintas a óleo de uma pintura), tudo o que nós designamos em nossa análise do livro como "mídia" se enquadra nessa definição (e pelo menos "livro" aparece em mais de uma categoria). No discurso midiático, o conceito de "mídia" abrange nitidamente categorias diversas, embora intrinsecamente ligadas entre si, que só devem ser diferenciadas de modo mais categórico quando o interesse da pesquisa assim o exigir. É importante insistir que essa definição coloca o peso principal sobre os processos de comunicação e não sobre as técnicas de produção.

Um caso especial, que necessita de esclarecimentos mais precisos, é o da diferenciação entre relações intermidiáticas e textos intermídias. Da forma como aparece em diversas contribuições no livro de Helbig, o conceito de "intermidialidade" cobre pelo menos três formas possíveis de relação:

1. relações entre mídias em geral (relações intermidiáticas);

2. transposições de uma mídia para outra (transposições intermidiáticas ou intersemióticas);

3. união (fusão) de mídias.

Textos multimídias e mixmídias pertencem à terceira categoria, do mesmo modo que textos intermídias, já definidos neste trabalho, mas ainda não discutidos. Marcas de firmas ou logotipos oferecem freqüentemente exemplos surpreendentes, como o logotipo de uma grande construtora em São Paulo, Sobloco (Fig. 2), que aparecia não só nos tapumes das obras, mas também nos topos dos arranha-céus em construção, dominando a silhueta da cidade, ao lado de logotipos semelhantes de outras firmas, todos iluminados à noite.

\footnotetext{
${ }^{24}$ BOHN; MÜLLER; RUPPERT. Die Wirklichkeit, p. 10; cf. MÜLLER. Intermedialität, p. 81.
} 


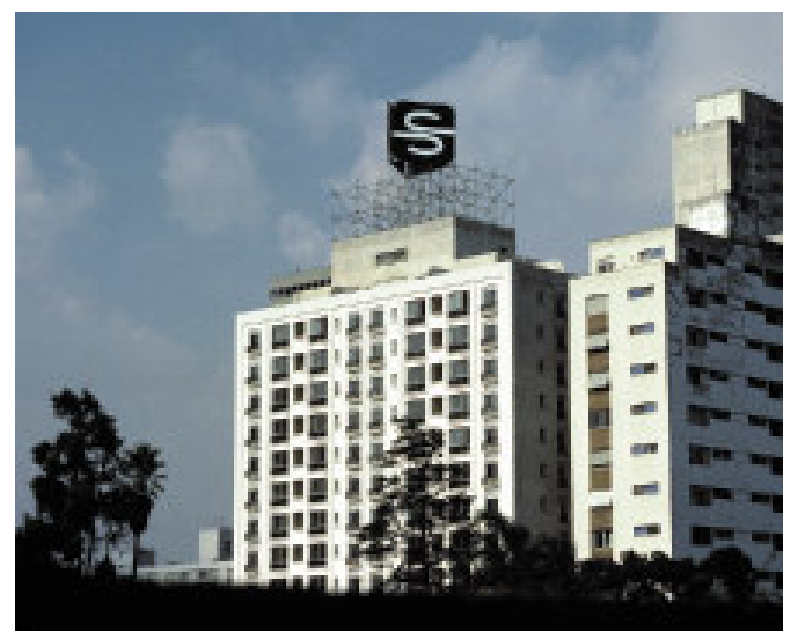

Fig. 2: Logotipo da construtora "Sobloco" no topo de um prédio em São Paulo, 1980.

Foto: Claus Clüver.

Esse signo parece ser uma letra, mas não pertence a nenhum sistema de fontes vigente. A maioria dos transeuntes vai lê-lo, todavia, sem esforço como um $S$, pois sabe que representa a firma Sobloco. Ele é formado pela combinação de um signo visual e de sua inversão, que, nesse contexto, representa visualmente o extremo curvado das vigas de ferro, utilizadas na construção de edifícios. O texto consiste, portanto, de uma dupla sinédoque: a letra inicial aponta para o nome completo da firma ${ }^{25}$ e a linha curva, como signo icônico, para uma parte do material de construção que, afinal, representa a obra toda. Extraído do contexto apropriado, o minitexto perde sua identidade midiática: ele não tem, para usarmos a terminologia de Peirce, nem caráter claramente simbólico, nem claramente icônico. Aqueles que encontram o signo fora do contexto não irão necessariamente lê-lo como um S (portanto, como uma letra). E, quando até mesmo um leitor acostumado a métodos modernos de design procurar entender o signo como logotipo, ele pode simplesmente não considerar a possibilidade de que as linhas curvas possam pertencer a outro sistema sígnico. Dentro do contexto da publicidade da construtora, porém, a mensagem verbovisual do logotipo está clara e efetiva. Note-se que seu efeito resulta da fusão indissolúvel de signos que pertencem a dois sistemas sígnicos diferentes: sem valer como letra, as linhas curvas perdem também sentido e função enquanto signos icônicos.

É mais complicada a situação em um minitexto no qual vários sistemas sígnicos e mídias se unem indissociavelmente uns com os outros. $O$ "Pentahexagrama para John Cage" (Fig. 3), de Augusto de Campos, expressa a admiração do poeta pela obra do americano através de um jogo de várias manifestações aleatórias em um design simples, cujos elementos estão reduzidos a um mínimo. Ele se baseia nos códigos e convenções de sistemas sígnicos de origem ocidental e oriental. Num hexagrama do I Ching (uma das 64 figuras possíveis, todas elas possuindo significados convencionais) ampliado horizontalmente estão inscritos signos que representam na notação musical ocidental duas terceiras

\footnotetext{
${ }^{25} \mathrm{O}$ nome da firma, indiferente de onde ele originalmente provenha, é compreendido inevitavelmente como "só bloco" e, com isso, como equivalente lingüístico para a representação icônica das vigas de ferro que representam os materiais da indústria de construção.
} 
idênticas descendentes em semínimas. Isso faz com que, quando se transforma mentalmente o hexagrama num pentagrama pela supressão da linha superior e, por conseguinte, em uma pauta, elas permitem soletrar CAGE segundo uma das convenções das notações musicais. Uma permutação para o outro pentagrama implícito pela supressão da linha inferior resulta em AFEC - uma seqüência de letras semanticamente vazia, a não ser que o leitor/manipulador do texto consiga descobrir um significado num léxico qualquer ou numa lista de acrósticos. O texto oscila, assim, no plano dos valores das letras entre sentido e não-sentido, mas ele contém sentido em ambas as versões enquanto minipartitura.

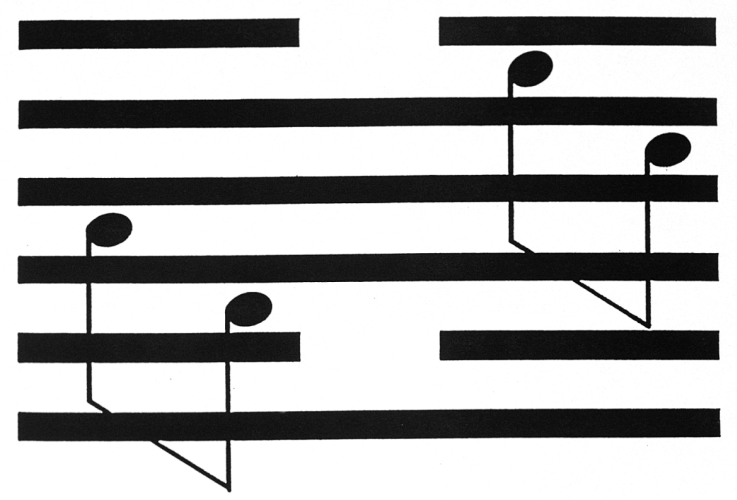

Fig. 3: Augusto de Campos (n. 1931), "Pentahexagrama para John Cage”, 1977. In: A. de Campos, Poesia 1949-1979. São Paulo: Livraria Duas Cidades, 1979. p.209.

A maneira como um leitor vai interpretar o texto na base desta análise dependerá consideravelmente de seu "léxico cultural" (Umberto Eco) e do grau de sua familiaridade com o indivíduo "nomeado" por meio de notas (e também do título). Considerando a tendência de o compositor americano promover processos aleatórios, o leitor pode se concentrar no acaso que permite representar o nome através de dois pares de notas com intervalos iguais; pode também lembrar-se de uma peça musical com as letras BACH (de acordo com outra convenção de identificação de notas musicais), que resultou numa composição bem conhecida. Esse texto, em contrapartida, não parece convidar à apresentação musical, apesar de que um músico acostumado com a transposição de partituras visuais de Cage e de seus contemporâneos talvez possa encontrar um caminho para tornar musicalmente interessante essa partitura minimalista e "aberta". Como uma combinação de signos visuais, ela, em vez disso, parece convidar à contemplação silenciosa, bem no sentido da fascinação de Cage por silêncios. Uma observação da seqüência de letras CAGE, expressa por notas, pode fazer com que ela se transforme num jogo de pensamento através de dois acréscimos em CHANGE [mudança], e esta, através da supressão de um pequeno traço, em CHANCE [acaso]. John Cage usava o I Ching na construção de suas composições aleatórias, o que justifica a utilização da figura de fundo, que atua também como linha musical passível de transformação. Leitores ocidentais que quiserem estudar o significado dessa figura irão consultar uma tradução do Livro das Mutações, enquanto um leitor educado na tradição cultural do Extremo Oriente possivelmente se aproximará do texto todo a partir do I Ching. A participação de diversos sistemas sígnicos justifica a designação desse texto como intersemiótico. Se 
o I Ching pode ser entendido como "mídia", então o "pentahexagrama" é também um texto intermídia, cujos elementos sígnicos ocidentais têm outras mídias como significados. É interessante notar o convite ao leitor para uma participação ativa: ele precisa manipular o texto mentalmente a fim de torná-lo legível como um todo.

Um último exemplo, no qual as mídias palavra e imagem estão intrinsecamente fundidas, serve de ilustração para as possibilidades de transportar um texto intermídias para outras mídias e conduz a outro texto que pode ser compreendido apenas como citação desse exemplo para, com isso, obter um efeito intertextual através da intermidialidade. $\mathrm{O}$ quadro LOVE (Fig. 4), de Robert Indiana, não é nem uma imagem no sentido comum, nem um caso normal de notação escrita de um signo verbal. ${ }^{26}$ Quem lê inglês, lerá esse texto primeiramente como uma palavra, apesar de não poder pronunciar essa versão especial da palavra, pois uma sonorização adequada deveria expressar também a forma e a ordem das letras, bem como a forma dos espaços vazios e, sobretudo, a inclinação do O. Esses são os traços característicos nos quais se reconhece o texto em todas as suas mutações e que determinam também a interpretação. Toda atribuição de sentido se ocupará da relação da informação visual com a palavra love e seu significado, que se estende de Eros a Ágape. Uma interpretação precisa considerar que cada letra toca outras duas e todos os lados do quadrado em que está inscrita, exceto o $\mathrm{O}$ inclinado, que não alcança a borda direita. Em comparação com as outras três letras, sua situação é precária e insegura, mas, em compensação, é também o único elemento potencialmente dinâmico. Os espaços entre as letras têm formas surpreendentes; pode-se atribuir a elas, pelo menos em parte, uma simbologia erótica. Já deveria estar claro que as relações entre signos e códigos num texto híbrido como esse vão desde o apoio semântico mútuo até o distanciamento irônico e a contradição direta - ou, pelo menos, as letras podem ser assim interpretadas.

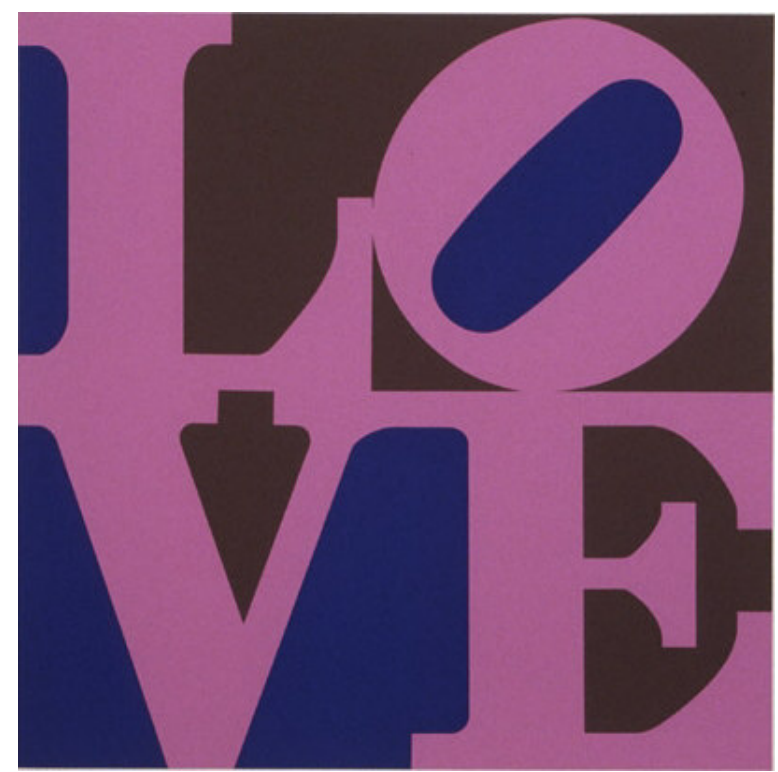

Fig. 4: Robert Indiana (n. 1928), LOVE, 1966. Óleo sobre tela, 72 x $72 \mathrm{~cm}$. Indianapolis Museum of Art. Cf. Prancha 1, p. 377

\footnotetext{
${ }^{26}$ Eu retomo aqui, em parte, considerações feitas em outro texto: ver CLÜVER. From Imagism to Concrete Poetry: Breakthrough or Blind Alley?, a respeito de Indiana p. 118-19; cf. também CLÜVER. Liaisons incestueuses: The Sister Arts in Contemporary Culture, a respeito de Indiana p. 26-27.
} 
Isso acontece também em relação às cores. Na pintura a óleo que se tornou pública como a primeira versão, as letras são em vermelho, enquanto os espaços vazios são parte em verde e parte em azul; o efeito do verde prevalece, provavelmente em virtude da proximidade com o vermelho; a justaposição dessas cores complementares dá a elas maior intensidade. Uma vez que o valor das cores é totalmente igual, nenhuma se destaca em relação às outras. Com sua superfície plana, o quadro parece completamente bidimensional e a relação entre figura e fundo torna-se ambivalente: nossa "ótica interior" pode se ajustar de tal modo que as formas dos espaços vazios aparecem como figuras e o vermelho das letras, por conseguinte, é visto como fundo. ${ }^{27}$

Como motivo gráfico, LOVE tornou-se um ícone popular nos anos 60 e 70. Carl Weinhardt relata que

De todas as imagens de Indiana, a mais reconhecida é LOVE, que ele executou em muitas variações de design, cores, tamanhos e mídias. Quando primeiro foi exposta ao público, a imagem respondeu tão bem ao gosto da época que foi copiada em milhões de artefatos comerciais e imitações ilegais, bem como em adaptações por amadores. ${ }^{28}$

Depois de realizar o motivo como pintura, Robert Indiana o utilizou em combinações múltiplas - por exemplo, como um novo quadrado formado por quatro inversões de LOVE, exibindo as letras $\mathrm{O}$ inclinadas para fora ou para dentro; ou como LOVE CROSS, em que o motivo se desdobra em todas as direções como sua respectiva imagem refletida. Além disso, ele também variou as cores, como na serigrafia intitulada Die deutsche Liebe [O amor alemão], encomendada em 1968, com letras amarelas e espaços vazios vermelhos e pretos. Entre as transformações mais interessantes figura a versão do motivo como escultura de aço medindo quase quatro metros de altura. Exposto ao ar livre, o aço Corten agora ficou coberto de ferrugem. Podemos caminhar em volta da palavra tridimensional e observar seu reverso, escalá-la e atravessála; em certa perspectiva, LOVE aparece quase como um cilindro a vapor (Fig. 5).

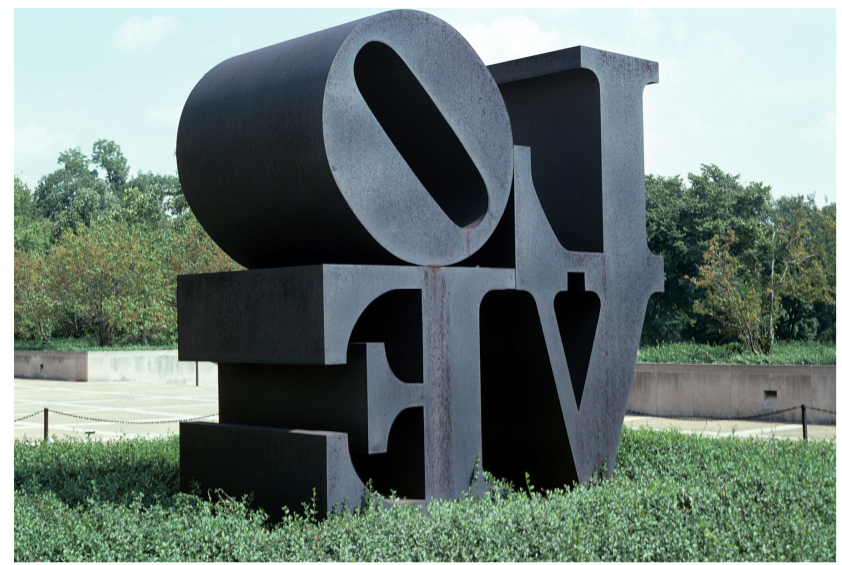

Fig. 5: Robert Indiana, LOVE. 1970. Aço Corten, 3,66 x 3,66 x 1,83 m. Indianapolis Museum of Art. Foto: Claus Clüver.

\footnotetext{
${ }^{27}$ Carl J. Weinhardt, Jr., ao comentar uma exposição, escreveu que "alguns observadores notaram que na série sobre LOVE, Indiana investigava os efeitos óticos da cor de uma maneira muito intensiva, chegando muito mais perto da Arte Op do que da Arte Pop" e citou uma nota de John McCoubrey: "Nas pinturas sobre LOVE, figura e plano de fundo tendem a ser percebidos como equivalentes". WEINHARDT. Robert Indiana, p. 157.
}

${ }^{28}$ WEINHARDT. Robert Indiana, p. 154. 
Weinhardt sempre fala de LOVE como um "logotipo", referindo-se simplesmente ao motivo gráfico; mas, de fato, para seu criador, ela se tornou algo como uma marca. Como indicado na citação, o motivo também foi explorado pelas mídias e pelo comércio. Uma das formas mais populares foi sua versão como selo postal, publicado em $1973 \mathrm{em}$ comemoração ao dia dos Namorados. Expedido milhões de vezes, esse "selo hippie" ajudou a preparar a recepção de uma escultura concebida nos anos 80 por artistas canadenses, que nos conduz quase ao final da nossa Petite histoire d'O.

A escultura AIDS (Fig. 6) obtém todo o seu efeito por sua referência ao logotipo de Indiana; assim, ela só pode ser compreendida enquanto citação, que é bastante evidente, principalmente quando se observa a ordem das quatro letras, em que o I no quadrante direito superior não atinge a borda, exatamente como o $\mathrm{O}$ na obra de Robert Indiana. Mas o I atua esteticamente de maneira bastante insatisfatória e mal conseguimos imaginá-lo inclinado como o $\mathrm{O}$ - uma conclusão a que chegamos apenas porque tentamos essa idéia como construção de variantes. Entretanto, o procedimento de inclinar a letra é citado em outro lugar, isto é, no espaço interno do D, cuja forma é alterada, o que se justifica, novamente, apenas pela referência a LOVE. Vemos AIDS e lemos LOVE; mas AIDS é feia. Exceto pelo fato de se tratar, em ambos os casos, de palavras de quatro letras, a intertextualidade desse texto intermídia se baseia nos signos visuais; contudo, sem o significado dos signos verbais, o todo não faria nenhum sentido.

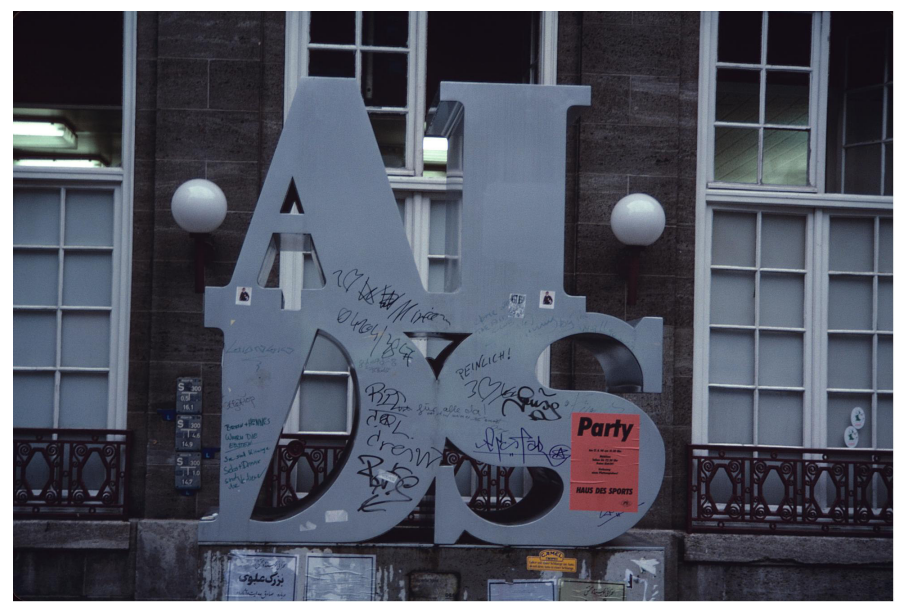

Fig. 6: AIDS. Escultura de metal de General Idea (Toronto), exposta temporariamente na Spitalerstraße, em Hamburgo, 1990. Foto: Claus Clüver.

O próprio Robert Indiana realizou uma transformação semelhante em 1977 com sua escultura AHAVA (Fig. 7), que é idêntica à escultura LOVE no tamanho e no material e que está em Jerusalém. ${ }^{29}$ "A escrita hebraica se lê da direita para a esquerda," escreve Weinhardt, "começando com o aleph (A) como o elemento à direita, em cima da pilha de letras. Uma ligeira curvatura [desta letra] dá uma aparência mais leve às formas compactas que os traços fortes do alfabeto hebraico criam quando este é colocado em formato tridimensional" ${ }^{30} \mathrm{~A}$ relação entre ambos os textos intermídias representa um caso especial de transposição

\footnotetext{
${ }^{29}$ Fotografia colorida em WEINHARDT. Robert Indiana, p. 202.

30 WEINHARDT. Robert Indiana, p. 200.
} 
intermidiatica, em que a mudança de uma língua para outra requer a permuta (novamente favorecida pelo acaso) de signos escritos de dois sistemas dentro da mesma estrutura sígnica, sendo que o traço mais característico do texto-fonte, o $\mathrm{O}$ inclinado, ${ }^{31}$ é substituído pela cursividade da letra hebraica que ocupa o lugar correspondente, aparentemente tratando-se de uma equivalência.

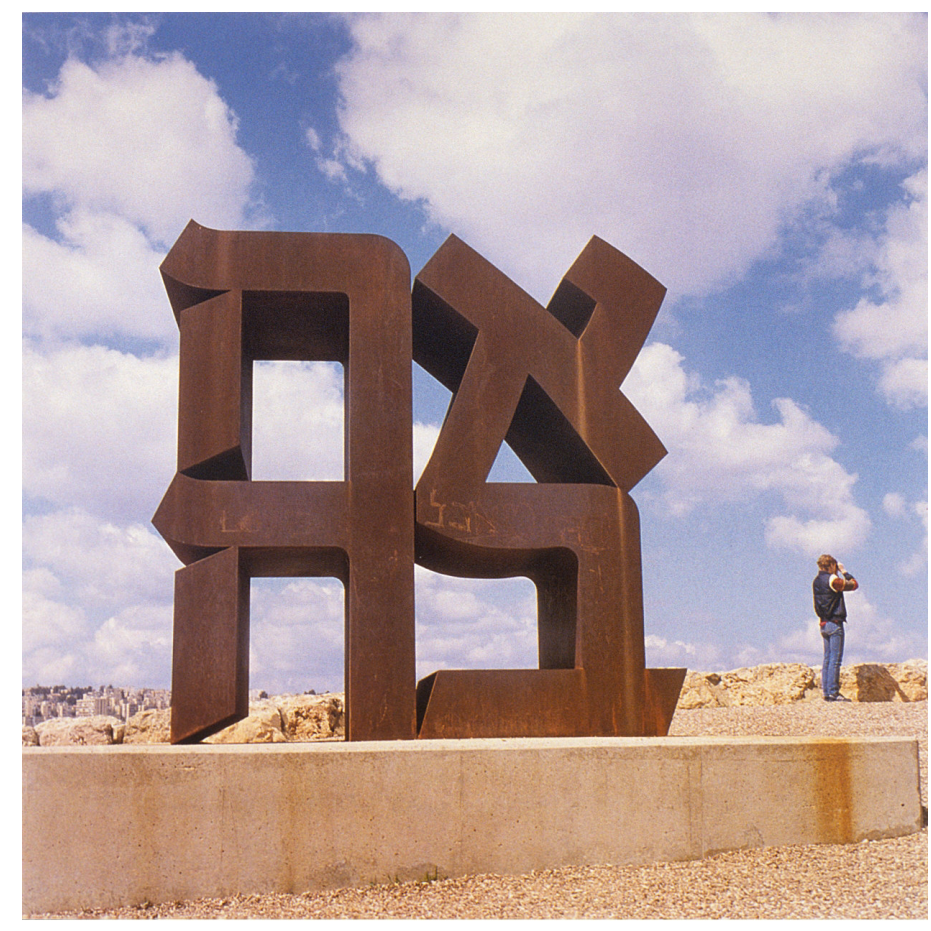

Fig. 7: Robert Indiana, AHAVA, 1977. Aço Corten, 3,66 x 3,66 x 1,83 m. Jerusalém: The Israel Museum. Cf. Prancha 2, p. 377

Nossa excursão por alguns poucos minitextos nos possibilita considerar o caráter intermídia de tais textos, sobretudo numa perspectiva semiótica. O logotipo de Indiana nos permite reconhecer, de modo especialmente nítido, a importância da distinção entre palavra e escrita, vistas como sistemas sígnicos diferentes, não apenas em virtude das tendências iconicizantes das próprias letras, mas também devido à semantização potencial dos espaços vazios entre elas. Ainda que não esteja claro se é possível considerar as figuras do I Ching não apenas como signos pertencentes a um sistema sígnico, mas também como representantes de uma mídia, tendo em vista as categorias intermidiáticas de textos multimídias e mixmídias, é bem mais apropriado falar de textos intermídias ao invés de textos intersemióticos. Textos intermídias puros, nos quais, portanto, acontece não uma mescla, mas sim uma fusão indissociável de propriedades e processos midiáticos, não aparecem tão freqüentemente. Como exemplos dessa categoria podemos citar os textos que Jérôme

\footnotetext{
${ }^{31}$ Indiana utilizou o O inclinado como sinédoque. Na sua contribuição para a comemoração do centenário da Estátua da Liberdade, por exemplo, um desenho da cabeça da estátua com o rosto exasperado e os olhos marejados, as letras O estão inclinadas no título "MOTHER OF EXILES" [Mãe dos Exilados], que aparece abaixo, grande, com letras estampadas típicas de Indiana, inevitavelmente uma alusão a um amor materno peculiar. Ver as ilustrações em WEINHARDT. Robert Indiana, p. 215.
} 
Peignot reuniu em Typoésie, bem como a maioria dos poemas sonoros. ${ }^{32}$ Muitos desses textos estão, por sua vez, integrados em textos mixmídia; a este tipo de mescla pertencem muitos poemas visuais e, sobretudo, textos publicitários em todas as mídias. Ainda não ouso analisar detalhadamente os aspectos intermidiáticos da mídia híbrida mais recente, os textos da Ciberliteratura. ${ }^{33}$ Textos intermídias puros que podem existir sem elementos verbais têm, em geral, um caráter performativo, como, por exemplo, certas peças musicais modernas que exigem daqueles que as executam gestos, movimentos e mudanças de lugar dos mais variados modos.

O nosso método de abordar todos os textos aqui apresentados abre caminhos interpretativos e críticos a obras de natureza intermidiática; além disso, ele ajuda a esclarecer a base conceitual e a terminologia de que necessitamos urgentemente para nosso trabalho, seja nos Estudos Interartes, seja no campo da Intermidialidade. A utilização indiscriminada do termo "intermidialidade" para todas as três relações midiáticas mencionadas anteriormente é complicada. Decidir se lidamos com um texto intermídia puro ou com parte de um texto mixmídia não é necessariamente a questão mais urgente; tais diferenciações são, entretanto, indispensáveis para uma teoria da intermidialidade. Mas elas também são relevantes para as tentativas de interpretação, pois o modo como pensamos sobre as relações dos signos dentro de um texto influencia nossa construção de sentido.

Transformações ou transposições de uma mídia a outra são - exatamente do mesmo modo que as diversas formas da combinação de mídias - formas de relações intermidiáticas, ao lado de uma série de outras formas. Parece lógico e prático utilizar "intermidialidade" como conceito geral para todas as formas de relação dessa natureza e não limitar o termo a formas específicas. Uma representação sistemática da relação entre transposição intermidiática e formas de combinação intermidiática nas relações entre palavra e imagem foi publicada por Leo Hoek em 1995 a partir de critérios que eu tinha formulado na minha Introduction. ${ }^{34}$ Seu título, La transposition intersémiotique: pour une classification pragmatique [A transposição semiótica: por uma classificação pragmática ${ }^{35}$ ], anuncia claramente a tendência semiótica de seu estudo, que parece tê-lo levado a preferir designações que evitam a referência às mídias. ${ }^{36}$ Em The Eternal Network: Mail Art, Intermedia Semiotics, Interarts Studies [A Rede eterna: Mail Art, Semiótica de Textos Intermídias, Estudos Interartes], texto publicado em 1997, Eric Vos resumiu as considerações propostas por Hoek e por mim num esquema derivado de Hoek, que adaptei às necessidades deste ensaio, reintroduzindo os termos de Hoek em itálico; os termos em inglês estão em negrito. ${ }^{37}$

\footnotetext{
${ }^{32}$ Ver sobre isso MENEZES. Poesia Sonora. Cf. também SCHOLZ. Bezüge zwischen 'Lautpoesie' und 'visueller Poesie'. Ver também: CLÜVER. Concrete Poetry and the New Performance Arts.

${ }^{33}$ Ver BARBOSA. A Ciberliteratura; KAC. Media Poetry; HELBIG. Der Rezipient als Cybernaut: Gedanken zur Poetik des elektronischen Romans; THOMSEN e THOMSEN. Digitale Bilder, virtuelle Welten: Computeranimation; e REIS. Repercussões do uso criativo das tecnologias digitais.

${ }^{34}$ CLÜVER. Interarts Studies: An Introduction.

${ }^{35}$ HOEK, Leo H. A transposição intersemiótica: por uma classificação pragmática. In: ARBEX, Marcia. Poéticas do visível.

${ }^{36} \mathrm{HOEK}$. La transposition intersémiotique, p. 77. Seus termos podem também ser condicionados pela língua francesa.

${ }^{37}$ VOS. The Eternal Network, p. 327 (a seqüência dos termos foi alterada).
} 


\begin{tabular}{|c|c|c|c|c|}
\hline & $\begin{array}{l}\text { relações } \\
\text { transmidiáticas } \\
\text { transmedial } \\
\text { relations } \\
\text { relation } \\
\text { transmédiale }\end{array}$ & $\begin{array}{l}\text { discurso } \\
\text { multimídia } \\
\text { multimedia } \\
\text { discourse } \\
\text { discours } \\
\text { multimédial }\end{array}$ & $\begin{array}{l}\text { discurso } \\
\text { mixmídia } \\
\text { mixed-media } \\
\text { discourse } \\
\text { discours mixte }\end{array}$ & $\begin{array}{l}\text { discurso } \\
\text { intermídia } \\
\text { intermedia } \\
\text { discourse } \\
\text { discours } \\
\text { syncrétique }\end{array}$ \\
\hline $\begin{array}{l}\text { separabilidade } \\
\text { distinctiveness } \\
\text { séparabilité }\end{array}$ & + & + & + & - \\
\hline $\begin{array}{l}\text { coerência/ } \\
\text { auto-suficiência } \\
\text { coherence/ } \\
\text { self-sufficiency }\end{array}$ & + & + & - & - \\
\hline $\begin{array}{l}\text { politextualidade } \\
\text { polytextuality }\end{array}$ & + & - & - & - \\
\hline $\begin{array}{l}\text { produção simultânea } \\
\text { simultaneous } \\
\text { production }\end{array}$ & - & - & + & + \\
\hline $\begin{array}{l}\text { recepção } \\
\text { simultânea } \\
\text { simultaneous } \\
\text { reception }\end{array}$ & - & + & + & + \\
\hline $\begin{array}{l}\text { tipo de relação } \\
\text { type of } \\
\text { relationship }\end{array}$ & $\begin{array}{l}\text { transposição } \\
\text { transposition }\end{array}$ & $\begin{array}{l}\text { justaposição } \\
\text { juxtaposition }\end{array}$ & $\begin{array}{l}\text { combinação } \\
\text { combination }\end{array}$ & $\begin{array}{l}\text { união / fusão } \\
\text { union/fusion }\end{array}$ \\
\hline
\end{tabular}

Todas as categorias se referem a textos distintos e à sua produção e recepção. Cito o esquema porque ele representa visualmente os critérios decisivos e inclui a transposição como categoria. Mas ele é inevitavelmente estático e trata os textos como objetos. Como Vos demonstra, isto tem algo em comum com o modo como Dick Higgins e também Peter Frank empregaram o conceito de "intermídia" (intermedium), isto é, como relacionado à localização de um texto entre as mídias tradicionais. Em 1965, Higgins escreveu: "Assim o happening desenvolveu-se como um intermedium, um território inexplorado, situado entre colagem, música e teatro". ${ }^{38}$ Mais tarde, ele modificou o conceito e o contrapôs a mixed media (por exemplo, "pinturas que incorporam poemas em seus campos visuais"): "Em intermedia [...] o elemento visual (pintura) se funde conceitualmente com as palavras". ${ }^{39}$ Higgins, que introduziu a palavra intermedium (intermídia) com sua respectiva forma plural no vocabulário da crítica moderna, reportou-se, para isso, à sua utilização "nos escritos de Samuel Taylor Coleridge, [que usou o termo] em 1812 exatamente no sentido contemporâneo - para definir obras conceitualmente situadas entre mídias já conhecidas". Essa sanção histórica parece

${ }^{38}$ HIGGINS. Intermedia, p. 22. Higgins publicou a primeira parte do texto em 1965, em Something Else Newsletter $\mathrm{n}^{\mathrm{O}}$ 1; a parte adicional das páginas 23 a 28 foi escrita em 1981.

${ }^{39}$ HIGGINS. Intermedia, p. 24. Cf. FRANK. Intermedia: Die Verschmelzung der Künste. Palestra proferida no Museu de Arte de Berna, em 31 de maio de 1987. 
basear-se num erro; ${ }^{40}$ todavia, a citação ressalta a diferença conceitual em relação ao princípio semiótico de Hoek. À visão estática, que caracteriza ambas as posições devido a seu foco no texto e suas propriedades, pode se contrapor a definição de um texto intermídia proposta por J. Müller que citamos anteriormente, que fala de uma "fusão e interação de processos e procedimentos midiáticos distintos". Mas a definição não oferece qualquer informação sobre onde esses processos dinâmicos acontecem. Esquemas como o apresentado acima, mesmo que sejam úteis, não têm possibilidade de abranger os diversos aspectos performativos da recepção, que investiguei em outro artigo, onde discuti os desenvolvimentos tanto na construção de textos quanto na formação teórica nos últimos cinqüenta anos. ${ }^{41}$ Espero ter indicado na discussão de alguns dos exemplos acima a importância de atos performativos na recepção ou na manipulação física de textosobjetos (como no livro Peephole) ou na performance mental, na decisão de como ler um texto (como na vacilação entre pentagrama e hexagrama no poema sobre John Cage).

O esquema de Hoek se refere às relações entre "texto" (individual) e "imagem" (individual), onde mais de uma mídia toma ou pode tomar parte em ambos os lados, e onde todas as possibilidades de interação entre escrita e imagem se oferecem à investigação (como o fez, por exemplo, Anne-Marie Christin em L'image écrite). Já que esta observação problematiza o modelo apenas aparentemente binário, encontramos na categoria da transposição um complexo de relações que o esquema não pode representar de forma alguma, e não se propõe a representar. Hoek, que situa nessa categoria tanto as descrições de imagens por historiadores e críticos de arte, como também as transposições literárias de imagens, aponta para as descrições freqüentes de imagens ficcionais, por exemplo, em romances, de modo que a "politextualidade" tem, em tais casos, um lugar vazio. Especialmente interessante e igualmente irrepresentável é a existência de várias transposições do mesmo texto-fonte não apenas em diversos gêneros (inclusive gêneros não-artísticos), mas também em diversas mídias: as relações intertextuais entre todas essas versões podem influenciar consideravelmente a recepção de uma determinada transposição. As adaptações de textos (na maioria, literários) por diversos meios de comunicação de massa resultaram num fenômeno que Karl Prümm descreveu em 1988 de maneira eloqüente, mas nomeou com um rótulo questionável: "Pode se falar, então, de multimidialidade quando um objeto estético está disponível e é passível de recepção em várias mídias". ${ }^{42}$ Prümm remeteu também a um "novo tipo de autor multimidiático". O tipo antigo é aparentemente o

\footnotetext{
${ }^{40}$ HIGGINS. Intermedia, p.23. - Jürgen Müller ocupou-se da questão e relatou: "Mesmo quando Coleridge remete constantemente em sua obra a interdependências midiáticas, ele emprega o conceito de 'intermídia' pela primeira vez e em primeiro lugar, no contexto de sua teoria narrativa: 'A alegoria narrativa se distingue da mitologia da mesma forma como a realidade se distingue do símbolo; ela é, em suma, o próprio intermedium entre pessoa e personificação. Quando fica individualizada demais, deixa de ser alegoria [...]'. ['Narrative allegory is distinguished from mythology as reality from symbol; it is, in short, the proper intermedium between person and personification. Where it is too strongly individualized, it ceases to be allegory'].” MÜLLER. Intermedialität, p.76, n.181; MÜLLER. Intermedialität als poetologisches und medientheoretisches Konzept, p. 31. Entretanto, Müller não percebe que Coleridge fala de uma posição mediana: a alegoria se situa a meio caminho entre pessoa e personificação - mas estas não são mídias. Coleridge está citado a partir RAYSOR. Coleridge's Miscellaneous Criticism, p. 33.

${ }^{41}$ CLÜVER. Concrete Poetry and the New Performance Arts.

${ }^{42}$ PRÜMM. Intermedialität und Multimedialität, p. 199.
} 
autor com talento múltiplo, agora substituído por alguém "que dispõe habitualmente de vários 'canais' e deles se serve sem preconceito". ${ }^{43}$ Nesta frase o autor aludiu aos preconceitos em relação aos meios de comunicação de massa por parte dos críticos e teóricos mais conservadores, contra os quais dirigiu sua polêmica. Mesmo que seu discurso tenha soado convincente, seu emprego do termo "multimidialidade" (Multimedialität), mesmo se lógico, discordou do uso convencional e, consequentemente, não se impôs.

Outro modelo, inspirado na relação entre Literatura e Música, mas que se baseia numa teoria da intermidialidade mais amplamente construída, foi proposto por Werner Wolf em 1999. Como demonstra sua definição de "mídia" e ressaltam suas exposições, sua visão também é orientada semioticamente:

"[M]ídia" pode ser definida [...] como um meio de comunicação convencionalmente distinto, especificado não só por canais (ou um canal) de comunicação particular(es) mas também pelo uso de um ou mais sistemas semióticos que servem para transmitir mensagens culturais. ${ }^{44}$

Essa definição evidentemente permite a Wolf considerar também a Literatura, um sistema sígnico de segunda ordem, como "mídia", apesar de ela usar os mesmos canais de comunicação que textos verbais não-literários usam (se desconsiderarmos a dificuldade já discutida de se estabelecer tais diferenciações). Assim como Hoek e Vos, Wolf resume seu sistema em esquemas representados visualmente, mais precisamente em três esquemas que se constróem um sobre o outro: o primeiro aponta "intertextualidade" e "intermidialidade" como duas "formas intersemióticas", ${ }^{45}$ o segundo (o mais importante no nosso contexto) é reservado à "intermidialidade" 46 e o terceiro e mais complexo de todos é o esquema da "intermidialidade músico-literária", que se relaciona com o esquema das "áreas principais de estudos músico-literários" desenvolvido há alguns anos por Steven P. Scher. ${ }^{47}$ A diferenciação mais importante introduzida por Wolf é aquela entre "intermidialidade aberta/direta" (overt/direct intermediality) e "intermidialidade oculta/indireta" (covert/indirect intermediality), em que a primeira categoria contém "intermidialidade sem transformação midiática" e a segunda, relações intermidiáticas com tais transformações, com subcategorias formadas paralelamente em ambas. Tudo isso se relaciona a "formas básicas de envolvimento de duas mídias em uma obra ou texto" e prepara, com isso, a investigação específica de relações músico-literárias, que constituem o foco principal de interesse do livro. Grosso modo, a segunda categoria corresponde àquela das "relações transmidiáticas" em Hoek e Vos, com a diferença de que aqui somente a obra e, respectivamente, o texto são considerados, não se levando em conta, pelo menos no esquema, a produção ou recepção textual. Isto conduz à negação da "politextualidade", portanto, da propriedade que, em Hoek e Vos, diferencia essa categoria das outras três, mais do que qualquer outra. Textos multimídia e textos mixmídia figuram indiscriminadamente na categoria

\footnotetext{
${ }^{43}$ PRÜMM. Intermedialität und Multimedialität, p. 199-200.

${ }^{44}$ WOLF. The Musicalization of Fiction, p. 35-36.

${ }^{45}$ WOLF. The Musicalization of Fiction, p. 47.

${ }^{46}$ WOLF. The Musicalization of Fiction, p. 50.

${ }^{47}$ WOLF. The Musicalization of Fiction, p. 70. Cf. SCHER, Literature and Music, p. 237.
} 
da "intermidialidade aberta". O termo "intermídia" é até nomeado, porém rejeitado com a observação (que não deixa de ser legítima) de que criaria "confusão com 'intermidialidade' como um hipernome". ${ }^{48} \mathrm{Na}$ verdade, Wolf entendeu mal a categoria de textos intermídia: ele concebe tais textos como se estes contivessem significantes de uma outra mídia, ou como se significantes heterogêneos tivessem sido transformados em significantes adequados à mídia. ${ }^{49}$ Por conseguinte, ele as considera como casos de "intermidialidade oculta". A incorporação adequada de textos intermídia (seja lá sob qual relação) no rótulo "aberta" exigiria, entretanto, uma revisão e reformulação do critério principal que caracteriza esse rótulo: "os significantes de duas mídias são aparentes e distintos" e "a princípio podem ser citados separadamente". ${ }^{50}$

Ensaios como os de Wolf, mais profundos e mais abrangentes do que, por exemplo, o de Hoek, concebido de outro modo e estimulante à sua maneira, fornecem um bom ponto de partida para o desenvolvimento de seus princípios teóricos. Ele parece fornecer, absolutamente, o fundamento teórico necessário para investigar "a musicalização da narrativa literária", apesar do problema de se fazer da "obra” por si só o objeto de análise. O que acontece no plano da recepção não pode ser representado satisfatoriamente pelo esquema e coloca em questão a categoria da "intermidialidade coberta". E a relação Literatura-Música é uma relação binária; não é possível reconhecer como o esquema poderia ser ampliado para representar as relações intermidiáticas mais complexas às quais a Música está associada, principalmente em nossos tempos. Apesar disso, tais esforços taxonômicos têm sua utilidade. Eles demonstram como pensamos atualmente sobre os fenômenos analisados, ajudam a esclarecer dificuldades conceituais e terminológicas e estimulam a revisão de nossos pressupostos paradigmáticos. Como não se trata da descoberta definitiva de categorias essenciais (ao invés da construção de modelos teóricos), tal formação modelar não convida a uma ordenação de textos e gêneros em compartimentos como meta final dos estudos da intermidialidade. Ao invés disso, ela desempenha certa função na nossa abordagem das relações intermidiáticas e de textos e instituições que criam tais relações ou que são por elas afetados. Desse modo, a categoria de textos intermídia se oferece como uma possibilidade de se compreender um texto desse tipo; mas, no processo da interpretação, questões sobre o significado de seus signos e de sua interação podem ser menos interessantes e importantes do que questões sobre a função de seus aspectos intermidiáticos e sobre suas funções nos contextos em que encontramos o texto. Lidar com o texto "enquanto tal" tornou-se difícil para nós, como demonstram os exemplos que discutimos.

\footnotetext{
${ }^{48}$ WOLF. The Musicalization of Fiction, p. 42, nota 89.

${ }^{49}$ WOLF. The Musicalization of Fiction, p. 42, nota 91. Como textos intermídias são relativamente raros no âmbito de interesse de Wolf, ele, aparentemente, não reconheceu a sua posição privilegiada. Mas tais textos não são raros na criação artística do século XX. Dentre eles figuram, por exemplo, certas formas de poesia sonora, bem como formas semelhantes a elas, principalmente na música eletrônica, especialmente em composições dos anos 50 e 60.

${ }^{50}$ WOLF. The Musicalization of Fiction, p. 50 (esquema) e p. 40.
} 


\section{Estudos Interartes - Estudos de Intermidialidade - Estudos Intermidiáticos}

Quando Jürgen Müller, especialista em Cinema e Televisão, apresentou, em alusão a Hans Robert Jauss, a "intermidialidade como provocação aos Estudos das Mídias", ${ }^{1}$ ele aderiu, em seu estudo do conceito de mídias, ao ensaio do especialista das mídias Knut Hickethier, intitulado Das "Medium", die "Medien" und die Medienwissenschaft [A "mídia", as "mídias" e os Estudos das Mídias], que limita o conceito plural "as mídias" aos modernos meios de comunicação de massa - Cinema, Televisão, Rádio e Vídeo, tratados nos Estudos das Mídias - e às mídias mais tradicionais como o jornal e as revistas. Mas Hickethier remete também à origem desses campos de estudo, sobretudo nos Estudos da Literatura e do Teatro, e afirma que, "ao lado dos Estudos das Mídias, que estão se tornando independentes, [...] haverá e deverá haver também um estudo das mídias nas demais disciplinas". ${ }^{52}$ O livro de Wolf, como sinaliza seu subtítulo, é um dos estudos mais recentes que parece comprovar essa afirmação; porém, em seu teor, é uma continuação do trabalho de autores como Steven Scher, que, por sua vez, baseou-se nos princípios fundamentais de Calvin Brown, cuja obra Music and Literature [Música e Literatura], de 1948, é considerada o documento fundador dessa área nos Estudos Interartes nos Estados Unidos. Em 1984, Scher reuniu trabalhos historicamente muito influentes e novos ensaios de autores de língua inglesa e de língua alemã nessa área em um manual, ${ }^{53}$ seguido logo depois pela obra Literatur und bildende Kunst ${ }^{54}$ [Literatura e Artes Plásticas], editada em 1992 por Ulrich Weisstein, concebida igualmente como um "Handbuch zur Theorie und Praxis eines komparatistischen Grenzgebiets" [Manual de teoria e prática de uma área comparatista limítrofe], ambas apresentando bibliografias detalhadas. A coletânea Word and Music Studies: Defining the Field [Estudos sobre palavra e música: definindo o campo], ${ }^{55}$ organizada por Walter Bernhart, Scher e Wolf e publicada em 1999, foi concebida como sucessora da coletânea de Scher, ${ }^{56}$ na medida em que mantém o esquema "Literatura e Música", "Música na Literatura" e "Literatura na Música" e alude, apenas em sua parte final, à maneira como se pode ir além dessa orientação binária. É importante notar que o livro também contém contribuições de musicólogos; porém, mesmo que todas as análises nela incluídas possam ser designadas de estudos de intermidialidade, não se encontra praticamente nada que pudesse exigir a substituição do conceito geral de "arte" pelo conceito de "mídia".

Mesmo as coletâneas de artigos sobre relações entre palavra e imagem publicadas na Alemanha desde o manual de Weisstein, que se valem do rótulo Intermedialidade ou seja, Intermedialität: Vom Bild zum Text ${ }^{57}$ [1994; Intermidialidade: da imagem ao texto],

\footnotetext{
${ }^{51}$ Intertextualität als Provokation der Medienwissenschaft; título do capítulo 1.2 de MÜLLER. Intertextualität.

52 " $[N]$ eben einer sich verselbständigenden Medienwissenschaft [wird es] dennoch auch weiterhin eine Medienforschung in den verschiedenen anderen Disziplinen geben und geben müssen". HICKETHIER. Das "Medium", die "Medien" und die Medienwissenschaft, p. 66.

${ }^{53}$ SCHER. Literatur und Musik. [Bibliografia: p. 404-420].

${ }^{54}$ WEISSTEIN. Literatur und bildende Kunst. [Bibliografia: p.320-343].

${ }^{55}$ BERNHART; SCHER; WOLF. Word and Music Studies.

${ }^{56}$ Este é o primeiro volume da série Word and Music Studies publicada pela editora Rodopi (Amsterdã e New York).

${ }^{57}$ EICHER e BECKMANN. Intermedialität.
} 
de Thomas Eicher e Ulf Beckmann, e a obra Icons - Texts - Iconotexts: Essays on Ekphrasis and Intermediality [1996; Ícones - textos - iconotextos: ensaios sobre écfrase e intermidialidade], organizada por Peter Wagner e já mencionada inicialmente - inserem-se totalmente no quadro dos Estudos Interartes tradicionais. Em contrapartida, os volumes publicados na série "Word\&Image Interactions" pela editora Rodopi, que contêm uma seleção das contribuições apresentadas nos encontros da International Association of Word and Image Studies, realizados a cada três anos, decidiram ir além desse quadro. Tal fato se explica, entre outras coisas, pela participação não apenas de historiadores da arte, mas também de teóricos das mídias. O conceito geral mais apropriado para abranger de modo genérico todos os trabalhos reunidos nesses volumes e, com isso, os Word and Image Studies, é "Intermidialidade". Esse conceito abrange, além dos Estudos das Mídias, igualmente os estudos midiáticos que Hinckethier queria ver continuados dentro de outras disciplinas relevantes, como, por exemplo, as relações da "mídia Literatura" com "as Mídias", às quais foi dedicada a coletânea Literaturwissenschaft - Medienwissenschaft ${ }^{58}$ [Estudos Literários - Estudos das Mídias], organizada por Helmut Kreuzer e publicada já em 1977.

Tal conceito - certamente possível em sua versão portuguesa como "Estudos da Intermidialidade" - apesar de os campos semânticos "Mídia" e "mídia" não coincidirem completamente - não é apenas um substituto apropriado para o conceito de "Estudos Interartes", mas também uma provocação ao campo de estudos inter-ou transdisciplinares designado por ele. Um campo de Estudos da Intermidialidade que não se ocupe apenas das relações entre os Estudos das Mídias e seus objetos, ou apenas das relações entre as artes tradicionais e as novas mídias, compreendidas como formas de arte, pelo menos incentiva contatos entre representantes de todas as disciplinas envolvidas. Assim, cria também a possibilidade de se divulgar interesses e métodos de pesquisa das diversas disciplinas ao lidar com objetos que pertencem também à esfera de interesse das outras. Os artigos que Jörg Helbig reuniu em seu livro ${ }^{59}$ dão, em sua totalidade, uma idéia dessa ampliação de perspectivas, apesar de eles, em grande parte, se originarem de especialistas em Literatura. Esse fato indica mais uma vez a predominância atual da mídia Literatura nos "Estudos Intermidiáticos", fato que se repete nos Estudos Interartes. Estes, assim compreendidos e ampliados, talvez sejam, no futuro, conhecidos internacionalmente como Estudos Intermidiáticos. Mas o uso inseguro da palavra-chave, "Intermidialidade", no livro de Helbig é um indício de que ainda há muito trabalho a se fazer na construção teórica dessa área. A contribuição mais importante que o Comparativismo pode prestar, hoje em dia, reside no fato de ele se ocupar das diversas culturas mundiais nas quais os textos inter e transmidiáticos de origem ocidental, cada vez mais divulgados no mundo inteiro, encontram outras tradições de produção textual intermidiática e outras maneiras de se pensar sobre elas.

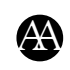

Tradução: Elcio Loureiro Cornelsen

Revisão: Eliana Lourenço de Lima Reis, Thaïs Flores Nogueira Diniz e Claus Clüver

\footnotetext{
${ }^{58}$ KREUZER. Literaturwissenschaft - Medienwissenschaft. Publicada como volume 6 da Biblioteca de Estudos “medium literatur", editada por Eberhard Lämmert.

${ }^{59}$ HELBIG. Intermedialität.
} 


\section{A B S TR A C T}

On the advantages and difficulties of reconceiving Interarts Studies as Intermedial Studies and constructing a theoretical basis for such studies, especially with regard to the concept of "medium" and "media" and the various meanings of "intermediality" in current usage.

\section{KEYWORDS}

Interarts Studies, Intermedial Studies, intertextuality, intermediality, intersemioticity

\section{REFERÊNCIAS}

BARBOSA, Pedro. A Ciberliteratura: Criação Literária e Computador. Lisboa: Edições Cosmos, 1996.

BARRICELLI, Jean-Pierre; GIBALDI, Joseph; LAUTER, Estella (Orgs.). Teaching Literature and Other Arts. New York: MLA, 1990.

BERNHART, Walter; SCHER, Steven Paul; WOLF, Werner (Orgs.). Word and Music Studies: Defining the Field. Amsterdã e Atlanta, GA: Rodopi, 1999.

A Bibliography on the Relations of Literature and Other Arts. BROWN, Calvin S. (Org., $1952-$ 72); SCHER, Steven Paul (Org., 1972-85); CLÜVER, Claus (Org., 1985-98). 1974 in Hartford Studies in Literature 7, p. 77-96. 1985-1998 in Yearbook of Comparative and General Literature: 34 (1985), p. 167-91; 35 (1986), p. 176-209; 36 (1987), p. 205-248; 37 (1988), p. 224-272; 39 (1990-91), p. 153-222; 43 (1995), p. 185-246; 45/46 (1997-98), p. 281-337. BOHN, Rainer; MÜLLER, Eggo; RUPPERT, Rainer. Die Wirklichkeit im Zeitalter ihrer technischen Fingierbarkeit. In: BOHN, Rainer; MÜLLER, Eggo; RUPPERT, Rainer (Org.). Ansichten einer künftigen Medienwissenschaft. Berlim: Ed. Sigma Bohn, 1988, p. 7-27.

BROWN, Calvin S. (Org.). A Bibliography on the Relations of Literature and Other Arts 19521967. New York: AMS, 1968.

BROWN, Calvin S. Music and Literature. Athens, GA: University of Georgia Press, 1948. [Reedição: Hanover, NH: University Presses of New England, 1987.]

BRYSON, Norman. Intertextuality and Visual Poetics. Style, v. 22, n. 2, p. 183-93, 1988. CHRISTIN, Anne-Marie. L'image écrite: ou la déraison graphique. Paris: Flammarion (Idées et Recherches), 1995.

CLÜVER, Claus. Bilder werden Worte: Zu Bildgedichten auf gegenstandslose Kunst. In: WEISSTEIN, Ulrich (Org.). Literatur und bildende Kunst: Ein Handbuch zur Theorie und Praxis eines komparatistischen Grenzgebiets. Berlim: Erich Schmidt, 1992, p. 298-315. CLÜVER, Claus. Concrete Poetry and the New Performance Arts: Intersemiotic, Intermedia[1], Intercultural. In: SPONSLER, Claire; CHEN, Xiaomei (Orgs.). East of West: Cross-cultural Performance and the Staging of Difference. New York: Palgrave, 2000, p. 33-61. CLÜVER, Claus. Concrete Poetry Into Music: Oliveira's Intersemiotic Transposition. The Comparatist, n. 6, p. 3-15, 1982. 
CLÜVER, Claus. From Imagism to Concrete Poetry: Breakthrough or Blind Alley? In: HAAS, Rudolf (Org.). Amerikanische Lyrik: Perspektiven und Interpretationen. Berlim: Erich Schmidt, 1987, p. 113-30.

CLÜVER, Claus. Interarts Studies: An Introduction. Publicado 1993 em tradução sueca. Em português: Estudos Interartes: Orientação Crítica. Trad. Yun Jung Im e Claus Clüver, revisão Helena Carvalhão Buescu. In: BUESCU, Helena Carvalhão; DUARTE, João Ferreira; GUSMÃO, Manuel (Orgs.). Floresta Encantada: novos caminhos da literatura comparada. Lisboa: Dom Qixote, 2001, p. 333-59; Bibliografia (sobre "Literatura e Outras Artes") p. 361-82.

CLÜVER, Claus. Klangfarbenmelodie in Polychromatic Poems: A. von Webern and A. de Campos. Comparative Literature Studies, v. 18, p. 386-98, 1981.

CLÜVER, Claus. Liaisons incestueuses: The Sister Arts in Contemporary Culture. In: BUESCU, Helena Carvalhão; DUARTE, João Ferreira (Org.). Entre Artes e Culturas. ACT2. Lisboa: Centro de Estudos Comparatistas, Faculdade de Letras; Colibri, 2000, p. 9-37.

CLÜVER, Claus. On Intersemiotic Transposition. Poetics Today, v. 10, n. 1, p. 55-90, primavera de 1989. Versão brasileira: Da Transposição Intersemiótica. Trans. DINIZ, Thaïs Flores Nogueira; CLÜVER, Claus; IM, Yun Jung, et al. In: ARBEX, Márcia (Org.). Poéticas do visível: ensaios sobre a escrita e a imagem. Belo Horizonte: Faculdade de Letras, Universidade Federal de Minas Gerais, 2006, p. 107-166.

CLÜVER, Claus. Teaching Comparative Arts. Yearbook of Comparative and General Literature, v. 23, p. 79-92, 1974.

DRUCKER, Johanna. The Century of Artists' Books. New York: Granary Books, 1995.

EICHER, Thomas; BECKMANN, Ulf (Orgs.). Intermedialität: Vom Bild zum Text. Bielefeld: Aisthesis Verlag, 1994.

FRANK, Peter. Intermedia: Die Verschmelzung der Künste. Berna: Benteli Verlag, 1987. GAITHER, Mary. Literature and the Arts. In: STALLKNECHT, Newton P.; FRENZ, Horst (Orgs.). Comparative Literature: Method and Perspective. Carbondale, IL: Southern Illinois University Press, 1961, p. 153-70.

HANSEN-LÖVE, Aage A. Intermedialität und Intertextualität. Probleme der Korrelation von Wort- und Bildkunst - Am Beispiel der russischen Moderne. In: SCHMIDT, Wolf; STEMPEL, Wolf-Dieter (Orgs.). Dialog der Texte: Hamburger Kolloquium zur Intertextualität. Slawistischer Almanach, vol. especial no⒒ Viena: Gesellschaft zur Förderung slawistischer Studien, 1983, p. 291-360.

HELBIG, Jörg. Der Rezipient als Cybernaut: Gedanken zur Poetik des elektronischen Romans. In: HELBIG, Jörg (Org.). Intermedialität: Theorie und Praxis eines interdisziplinären Forschungsgebiets. Berlim: Erich Schmidt Verlag, 1998, p. 81-92.

HICKETHIER, Knut. Das "Medium", die "Medien" und die Medienwissenschaft. In: BOHN, Rainer; MÜLLER, Eggo; RUPPERT, Rainer (Orgs.). Ansichten einer künftigen Medienwissenschaft. Berlim: Ed. Sigma Bohn, 1988, p. 51-74.

HIGGINS, Dick. Intermedia. In: HIGGINS, Dick. Horizons: The Poetics and Theory of the Intermedia. Carbondale and Edwardsville: Southern Illinois University Press, 1984, p. 18-28. 
HOEK, Leo H. La Transposition intersémiotique: Pour une classification pragmatique. In: HOEK, Leo H.; MEERHOFF, Kees (Org.). Rhétorique et image. Textes en hommage à A. Kibédi Varga. Amsterdã e Atlanta, GA: Rodopi, 1995, p. 65-80. Versno portuguesa: A transposiçno intersemiótica: por uma classificaçno pragmática. Trad. Márcia Arbex. In: ARBEX, Márcia (Org.). Poéticas do visível: ensaios sobre a escrita e a imagem. Belo Horizonte: Faculdade de Letras, Universidade Federal de Minas Gerais, 2006, p. 167-189. L'Intertextualité: Intertexte, Autotexte, Intratexte. Número temático. Texte: Revue de critique et de théorie littéraire, n. 2, 1983.

KAC, Eduardo (Org.). Media Poetry: An International Anthology. Bristol, UK: Intellect, 2007. Edição revisada, ampliada e atualisada de New Media Poetry: Poetic Innovation and New Technologies. Visible Language, v. 30, n. 2, 1996.

KREUZER, Helmut (Org.). Literaturwissenschaft - Medienwissenschaft. Heidelberg: Quelle und Meyer, 1977.

LAGERROTH, Ulla-Britta; LUND, Hans; HEDLING, Erik (Orgs.). Interart Poetics: Essays on the Interrelations of the Arts and Media. Amsterdã e Atlanta, GA: Rodopi, 1997.

MENEZES, Philadelpho (Org.). Poesia Sonora: Poéticas experimentais da voz no século XX. São Paulo: EDUC, 1992.

MOWITT, John. Text: The Genealogy of an Anti-Disciplinary Object. Durham e Londres: Duke University Press, 1992.

MÜLLER, Jürgen E. Intermedialität als poetologisches und medientheoretisches Konzept: Einige Reflexionen zu dessen Geschichte. In: HELBIG, Jörg (Org.). Intermedialität: Theorie und Praxis eines interdisziplinären Forschungsgebiets. Berlim: Erich Schmidt, 1998, p. 31-40.

MÜLLER, Jürgen E. Intermedialität: Formen moderner kultureller Kommunikation. Münster: Nodus, 1996.

MÜLLER, Jürgen E. Intermediality: A Plea and Some Theses for a New Approach in Media Studies. In: LAGERROTH, Ulla-Britta; LUND, Hans; HEDLING, Erik (Orgs.). Interart Poetics: Essays on the Interrelations of the Arts and Media. Amsterdã e Atlanta, GA: Rodopi, 1997, p. 295-304.

MÜLLER, Jürgen E. Video - or the Intermedial State of the Art. In: HEUSSER, Martin; CLÜVER, Claus; HOEK, Leo; WEINGARDEN, Lauren (Orgs.). The Pictured Word. Word\&Image Interactions II. Amsterdã e Atlanta, GA: Rodopi, 1998, p. 347-56.

PEIGNOT, Jérôme. Typoésie. Paris: Imprimerie Nationale Éditions, 1993.

PRÜMM, Karl. Intermedialität und Multimedialität: Eine Skizze medienwissenschaftlicher Forschungsfelder. In: BOHN, Rainer; MÜLLER, Eggo; RUPPERT, Rainer (Orgs.). Ansichten einer künftigen Medienwissenschaft. Berlim: Ed. Sigma Bohn, 1988, p. 195-200. RAYSOR, Thomas M. Coleridge's Miscellaneous Criticism. Folcroft, PA, 1936.

REIS, Pedro. Repercussões do uso criativo das tecnologias digitais da comunicação no sistema literário: o caso da poesia intermediática electrónica. 2004. Tese (Doutorado), Faculdade de Letras, Universidade de Lisboa, 2004. 
REMAK, H. H. H. Comparative Literature: Its Definition and Function. In: STALLKNECHT, Newton P.; FRENZ, Horst (Orgs.). Comparative Literature: Method and Perspective. Carbondale, IL: Southern Illinois University Press, 1961, p. 3-37.

SANTAELlA, Lúcia. Texto. In: JOBIM, José Luis (Org.). Palavras da Crítica. Rio de Janeiro: Imago, 1992, p. 391-409.

SCHER, Steven P. Literature and Music. In: BARRICELLI, Jean-Pierre; GIBALDI, Joseph (Org.). Interrelations of Literature. New York: MLA, 1982, p. 225-50.

SCHER, Steven P. (Org.). Literatur und Musik: Ein Handbuch zur Theorie und Praxis eines komparatistischen Grenzgebiets. Berlim: Erich Schmidt, 1984.

SCHMITT-VON MÜHLENFELS, Franz. Literatur und andere Künste. In: SCHMELING, Manfred (Org.). Vergleichende Litertaturwissenschaft: Theorie und Praxis. Wiesbaden: Akademische Verlagsgesellschaft Athenaion, 1981, p. 156-74.

SCHOLZ, Christian. Bezüge zwischen "Lautpoesie" und "visueller Poesie": Vom "optophonetischen Gedicht" zum "Multimedia-Text". In: ARNOLD, Heinz Ludwig (Org.). Visuelle Poesie. Coleção Text+Kritik, vol. IX, Aachen: Ed. Text+Kritik, 1997, p. 116-29.

THOMAS, Karin. Bis Heute: Stilgeschichte der bildenden Kunst im 20. Jahrhundert. Köln: DuMont, 1981.

THOMSEN, Kai; THOMSEN, Christian W. Digitale Bilder, virtuelle Welten: Computeranimation. In: HELBIG, Jörg (Org.). Intermedialität: Theorie und Praxis eines interdisziplinären Forschungsgebiets. Berlim: Erich Schmidt, 1998, p. 275-290.

VOS, Eric. The Eternal Network: Mail Art, Intermedia Semiotics, Interarts Studies. In: LAGERROTH, Ulla-Britta; LUND, Hans; HEDLING, Erik (Orgs.). Interart Poetics: Essays on the Interrelations of the Arts and Media. Amsterdã e Atlanta, GA: Rodopi, 1997, p. 325-36.

WAGNER, Peter (Org.). Icons - Texts - Iconotexts: Essays on Ekphrasis and Intermediality. Berlim: de Gruyter, 1996.

WEINHARDT, Carl J. Robert Indiana. New York: Harry N. Abrams, 1990.

WEISSTEIN, Ulrich. Exkurs: Wechselseitige Erhellung der Künste. In: WEISSTEIN, Ulrich. Einführung in die Vergleichende Literaturwissenschaft. Stuttgart: Kohlhammer, 1968, p. 184-97.

WEISSTEIN, Ulrich (Org.). Literatur und bildende Kunst: Ein Handbuch zur Theorie und Praxis eines komparatistischen Grenzgebiets. Berlim: Erich Schmidt, 1992.

WEISSTEIN, Ulrich. The Mutual Illumination of the Arts. In: WEISSTEIN, Ulrich. Comparative Literature and Literary Theory. Trad. William Riggan. Bloomington, IN: Indiana University Press, 1973, p. 150-66.

WOLF, Werner. The Musicalization of Fiction: A Study in the Theory and History of Intermediality. Amsterdã e Atlanta, GA: Rodopi, 1999.

ZIMA, Peter W. (Org.). Literatur intermedial: Musik - Malerei - Photographie - Film. Darmstadt: Wissenschaftliche Buchgesellschaft, 1995. 